EJM

51,3

572

Received 31 August 2015

Revised 12 November 2015

20 February 2016

Accepted 5 May 2016

\section{Integrating identity, strategy and communications for trust, loyalty and commitment}

\author{
T.C. Melewar \\ The Business School, Middlesex University, London, UK \\ Pantea Foroudi \\ Department of Marketing, Branding, and Tourism, The Business School, \\ Middlesex University, London, UK \\ Suraksha Gupta \\ Kent Business School, Canterbury, UK \\ Philip J. Kitchen \\ The Business School, University of Salford, Salford, UK and \\ ESC Rennes School of Business, France, and \\ Mohammad M. Foroudi \\ Brunel Business School, London, UK
}

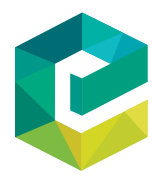

European Journal of Marketing Vol. 51 No. 3, 2017

pp. $572-604$

Emerald Publishing Limited 0309-0566

DOI 10.1108/EJM-08-2015-0616

\begin{abstract}
Purpose - This paper aims to operationalise and juxtapose variables related to identity, strategy and communications, and then examine the impact of such integration on organisational stakeholders' trust, loyalty and commitment by using commitment/trust theory.

Design/methodology/approach - This research design utilises explanatory research at the preliminary stage, as informed by the literature and conceptual framework. The subsequent model was examined via a positivist survey carried out among stakeholders in high-end retail stores in London. Structural equation modelling (SEM) via AMOS was conducted to gain insight into the various relevant influences and relationships.

Findings - The results indicate that identity and strategy are key drivers of integrated corporate communication, and they serve to build stakeholder trust, loyalty and commitment.

Originality/value - The paper shows that while practitioners have indicated that integrated marketing communication is important for organisations, there are a few other areas of concern with regard to consequences related to trust, loyalty and commitment, especially in a retail context. This paper empirically examined relationships between these constructs by validating a conceptual model by using SEM.
\end{abstract}

Keywords Communications, Commitment, Loyalty, Strategy, Identity, Trust

Paper type Research paper

(C) T.C. Melewar, Pantea Foroudi, Suraksha Gupta, Philip J. Kitchen, Mohammad M. Foroudi. Published by Emerald Publishing Limited. This article is published under the Creative Commons Attribution (CC BY 3.0) licence. Anyone may reproduce, distribute, translate and create derivative works of this article (for both commercial and non-commercial purposes), subject to full attribution to the original 43 publication and authors. The full terms of this licence may be seen at http://creativecommons.org/licences/by/3.0/legalcode. 


\section{Introduction}

Changes in the marketing environment with the introduction of new media are driving the need for more efficient and cost-effective communication (Low, 2000). Hence, managers approach, articulate and implement their company's marketing communication strategies using integrated tactics. Kitchen and Burgmann (2010) and Kitchen et al. (2004) suggest that marketing managers should consider integration of different marketing approaches not as part of their marketing mix, but as a holistic concept. The concept chosen should use all the elements of the marketing mix to promote and reinforce customer interactions and distribute integrated messages to the appropriate target audience. Companies that are obviously struggling to efficiently deliver their services and to survive in the global competitive market consider integrated marketing communication (IMC) as a strategy for aligning their marketing messages with the marketing objectives of managers and the target audience.

Kitchen et al. (2004) state that when IMC is enforced, it enables marketers to recognise the needs of stakeholders, particularly of employees and suppliers. Scholars also believe that is it not possible to have a global definition of IMC, although the main benefit of IMC is understood to be its capability to transfer reliable, consistent and allied messages to the target audiences through various channels (Low, 2000; Phelps and Johnson, 1996). The use of IMC to develop relationships and create a distinctive identity distinguishes the company from its competitors (Balmer et al., 2007; Van Riel and Balmer, 1997). A study by Kerr et al. (2008) explains IMC as a key communication tool which plays a significant role in building public and media relations. Effective advertising, sales promotion and direct marketing are the core channels for delivering messages with accuracy and reliability.

Research studies such as Gurau (2008) and Hallahan (2007) assert that the association between public relations and IMC achieves the purpose of creating a long-term customer-centric mindset and enhancing customer relationships. The aim of public relations is to generate signals to attract attention to one's brand/product and services by creating awareness through events and mass media (Kotler et al., 2005). Consequently, public relations has one of the most significant roles within the IMC process. Grunig (2006) stated that the public relations concept is an independent strategic function rather than being a marketing function or a component of IMC. Kotler et al. (2005) confirm that one of the important aims of public relations is to generate and provide information to an audience through mass media tools, attract their attention and generate awareness.

Previous research studies have explored these different issues in isolation and have argued about the variables that influence the context in which they operate, and they have failed to consider these factors from a retail perspective (Appendix 1). There is no research that discusses the operationalisation of variables related to identity, strategy and communications combined with a focus on trust, loyalty and commitment of stakeholders to an organisation, specifically by using commitment/trust theory. Integrating corporation into communications implies that it is important to create and accomplish stakeholders' perceptions towards the company. Simoes et al. (2005) state that the importance of "consistency in corporate communications has fuelled interest in integrated marketing communications".

The next section provides a brief, general discussion about the influence of nexuses between identity and strategy on IMC elements, which express our consumer-level conceptual framework. The section after that explains the methodology used by the authors to evaluate the proposed model. Finally, the authors conclude with a discussion of the theoretical significance of this study and implications and limitations of the research.

\section{Trust loyalty and commitment}

573 
EJM

51,3

574

\section{Identity}

The management of corporate identity is of great significance for the success of any organisation (Schultz and Kitchen, 1997). Although according to Melewar (2003) there is no common definition of corporate identity, the understanding of the concept of corporate identity is fairly homogenous. He used the common definition that "corporate identity is a mix of characteristics that a company possesses as a subject” (Melewar, 2003).

According to scholars, corporate identity is made up of the distinctive characteristics of a company which form a central and integrative function within the company and its competitive strategy. In addition, corporate identity performs a pivotal role which addresses four questions: "who you are, what you do, how you do it and where you want to go" (Balmer, 2001; He and Balmer, 2005, p. 6). In addition, identity is a powerful tool that influences the strategy content by providing a communication system to the company's stakeholders (He and Balmer, 2005). Balmer and Wilson (1998, p. 15) encapsulated this approach in the following definition:

corporate identity is the total of visual and non-visual means applied by a company to present itself to all its relevant target groups on the basis of a corporate identity plan.

Corporate identity is a unique feature that a corporation or brand transmits about itself, embracing values and communication. Furthermore, Balmer (2001) defines the corporate identity mix as communications that need to be integrated. Researchers have stated how corporate identity and its components should be communicated internally and externally (Balmer, 2001). Moreover, Cornelissen and Harris (2001, p. 56) clarified the definition of corporate identity as a "tangible symbol of the company's personality, the symbol which is manifest in the behaviour and communication of an organization". Abratt's (1989) model considers the concept of "interface" in corporate identity and corporate image. Organisations harmonise both internal and external communications to generate favourable images of the company for target audiences. The following communicators of the corporate image were mentioned: nomenclature, formal statements (mission), corporate communication, visual identity, graphics and imagery (company stationary) and promotional media (public relations and advertising). It is important that these sources communicate a consistent image to the company's internal and external stakeholders (Cian and Cervai, 2014).

\section{Strategy}

IMC is "the strategic coordination of all the company's messages as well as the media used by an organisation to impact on the company's perceived value". By integrating the communication strategies, synergies are created among different forms of communication. All forms of communication that express an image and seek an integrated approach to articulate a company's identity should be consistent messages which are transmitted by external and internal methods of communication (Simoes et al., 2005). Gilly and Wolfinbarger (1998) analysed the impact of advertising upon an internal audience and the importance of involving employees in communications; they stressed the need for integrated and consistent communications. Communication effectiveness may relate to customers' previous familiarity with the advertised brand or company (Campbell and Keller, 2003). Corporate personality is defined by Abratt (1989, p. 413) as the sum total of the characteristics of the company - behavioural and intellectual characteristics - which serve to distinguish one organisation from another. Some authors (Balmer and Wilson, 1998; Van Riel and Balmer, 1997) believe that these characteristics are the attitudes and beliefs which are shared by the organisation's employees. The link between corporate brand identity and strategy is very significant, as it illustrates the company's aims, ethos and values. All these factors 
potentially demonstrate a sense of distinctiveness that can distinguish an organisation from its competitors through the company's visual cues.

\section{Marketing communication}

It is vital for an organisation's marketing managers to realise which communication tools, channels and messages are more powerful in the company's stakeholders' perception (Kitchen, 2005). Additionally, managing the company's identity and its communication should be based on the company's consumers' response towards the messages, so it is important to examine communication from a receiver's viewpoint to reveal how organisational cues are collected and interpreted. Stakeholders can be passive receivers of organisation communication, and can also positively influence organisations. Van Riel and Balmer (1997) assert that a company's communications can play a critical role, for instance, in regard to corporate personality and corporate visual identity, which are recognised in the literature of corporate identity. Abratt's (1989, p. 203) model, called "the corporate image management process", was the first attempt to show the link between personality, identity and image, which sets out the foundation for corporate image. The visual/graphic designers and marketers realised the effectiveness of consistency in design and marketing communications, which affect the consistency of the company's formal corporate communications (Van Riel and Balmer, 1997). Communicators such as advertising, corporate logo, buildings, etc. can form the customers' perceptions of the intended corporate identity. The essence of a brand is externally embodied in the form of a corporate logo, which is always present and is important as a product and corporate differentiator to convey a favourable corporate image (Foroudi et al., 2014; Hatch and Schultz, 2001; Henderson and Cote, 1998) when compared to competitors (Kotler, 2000).

The concept of communication can be considered as a bridge that links the company's identity with the image of the company (He and Mukherjee, 2009, p. 3). In addition, it can influence the company's strategy and provide a corporate communication system to the stakeholders (Hatch and Schultz, 1997; He and Mukherjee, 2009). Stuart (1999) states that he "considered that both organisational and marketing communications are the central forms of communication between identity and image". Also, communication can shape the connection between a company's personality and identity (p. 204). Van Rekom (1997, p. 411) highlights how the purpose of corporate communications is to improve a certain desired corporate image for target audiences. According to Simoes et al. (2005, p. 156), gaining a competitive advantage from messages needs the integration of communications between internal and external stakeholders.

\section{Conceptual framework overview}

Our model articulates the individual-level dynamics of IMC in terms of two relationships. The conceptualised model emphasises the relationship between the concept of identity and strategy and the main antecedent of IMC and its outcomes. This study argues that in the current era of unprecedented organisational impacts and consumerism, some companies offer meaningful controlled and uncontrolled communication to their audience which assists them in satisfying their chief self-definitional requirements. Therefore, such organisations establish communication through different cues to create valid targets for trust, loyalty and commitment among relevant consumers, even though these are not prototypical consumers.

We suggest that identity:

forms a central and integrative function within the corporate and competitive strategy and that corporate identity forms a pivotal role which can influence the strategy content as well as providing a corporate communication system to stakeholders (He and Mukherjee, 2009, p. 3). 
$\mathrm{EJM}$

51,3

576

Creating a consumer-level conceptual framework based on commitment/trust theory shows that the ideal identity is the optimum philosophy, vision and value (Hatch and Schultz, 1997; Simoes et al., 2005), personality (Aaker, 1997) and the organisation's positioning in its marketplace (or markets) (Das, 2014) in a given time frame which inspires trust, loyalty and commitment from consumers (Figure 1). The model also reflects a link between consumers' perceptions of a company or brand identity to strategy which is linked to IMC (controlled communication and uncontrolled communication). Specifically, customers are more likely to use their perceptions of company strategy from their judgement about brand/company distinctiveness; brand/company social responsibility (link between competitive advantage and corporate social behaviour in generic ways); and governance, which is empowerment either explicitly or implicitly by governments and international organisations with the right to make decisions for others. Reactions of consumers in this setting depend on the extent to which they receive information from communication tools that they know and trust; these may generate loyalty and commitment to the company or brand.

We reflect on the argument of Kitchen (2005) that communication has a wide influence on how an organisation presents its image verbally and visually. Communication can be considered as the aggregate of messages from official and unofficial sources, via a diversity of media, whereby a company can transfer its identity to its various audiences (Melewar, 2003). Brown and Dacin (1997) state that strategic management puts a substantial effort into the company's identity management; however, it is not easy to understand whether it is the planned communication response to the company's efforts that influence the internal stakeholders' perception. Some scholars have emphasised the importance of consistency between identity and communication (Van Riel and Balmer, 1997). In addition, the strategic management of messages and the media employed by an organisation influence its perceived value. IMC as a key concept of marketing communications planning can add value and be used to evaluate the company's strategic roles (for example, sales promotion, direct response, general advertising and public relations), and associations of all these disciplines can deliver consistency, clarity and maximum communications impact (Schultz and Kitchen, 1997, p. 9).

\section{Identity, strategy, controlled communication and uncontrolled communication}

Corporate identity is demonstrated in an organisation's communications (Balmer and Wilson, 1998; Cornelissen and Harris, 2001; Van Riel and Balmer, 1997). Communication is also the touchstone for demonstrating an identity and is recognised as such in the

Figure 1.

The conceptual framework

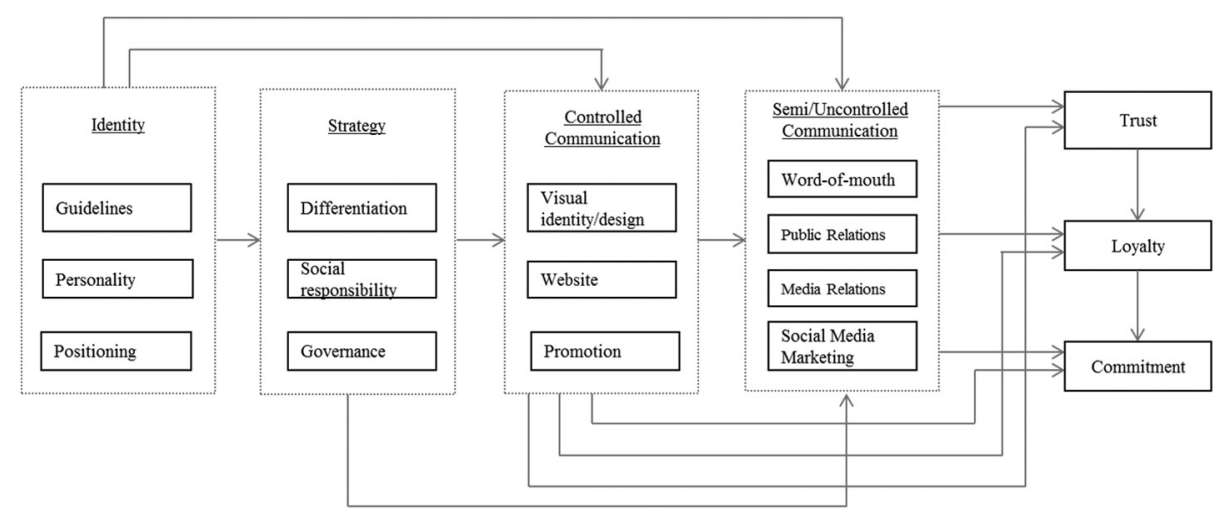


identity-creation process. Communication is everything in and about an organisation and it has an extensive impact. Studies on consumer behaviour have extensively acknowledged that communication - from company stationary to promotion and internal/external communications - influences stakeholders' behaviour and attitudes (Lau and Ng, 2001). According to Belch and Belch (2011), advertising is a key element of promotion in organisations, as it informs their audience about their brands, their key benefits, accessibility and position, while IMC puts emphasis on supporting a consistent message to demonstrate their brands through diverse ways (Kliatchko, 2008). Luck and Moffatt (2009) claimed that the role of promotion in IMC is to deliver adequate information to the audience about the brand in a way that is consistent with how the firm describes its identity and image. In addition, they recommend that promotion contributes to a very distinctive identity, by maintaining the reliability shaped by the brand. This is predominantly important in the context of IMC, as it stresses the brand image formed by the company. Furthermore, Belch and Belch (2011) then proposed that the key vital value of IMC is to demonstrate the integrity of the product to customers, regardless of the kinds of communication tools elected to convey the message.

Corporate communication can impact on the organisation's uniqueness in addition to its products and services, sales promotion, sponsorship and direct selling, advertising, corporate advertising and public relations activities (Barich and Kotler, 1991). A company communicates in both a controlled and an uncontrolled manner to make the organisation distinctive. Therefore, in addition, public relations and corporate advertising activities are directed at brand recognition and familiarity rather than at individual promotions communicating a company's corporate identity. Appendix 1 illustrates the notion of integrating identity, strategy and communications for trust, loyalty and commitment from key authors.

Corporate communications have been classified into internal and external and are considered as a function of human resources, public relations and marketing communications departments in an organisation. As explained in existing academic literature, these departments use corporate communications for communicating with internal and external audiences about policy, crises, promotions, marketing initiatives, etc. by means of various vehicles such as logo, fonts, typefaces, code of conduct, email etiquettes, branding, recognition rewards, customer relationship strategies, marketing collaterals, etc. Van Riel (1995) reviewed corporate communications from an organisational function point of view and classified them into management communications, marketing communications and organisational communications. Classification of corporate communications by Balmer (1995) indicates that the corporate communications mix incorporates primary, secondary and tertiary communications. The embeddedness of a company's communications to stakeholders into concepts like mission, vision, strategies, identity, image, reputation is also reflected in marketing literature by authors such as Lau and Ng (2001). Barich and Kotler (1991) explain that controlled marketing communication activities position a company's brand in the marketplace, as well as promote the company itself. Simoes et al. (2005) refer to corporate identity as an uncontrolled communication and reflect on it as the way in which an organisation's identity is revealed through its behaviour and symbolism towards internal and external audiences. Based on this, the following hypotheses are derived:

H1. The more favourable the brand identity is perceived by consumers, the more favourable the attitude consumers have towards the brand strategy. 
EJM

51,3

578

H2. The more favourable the brand identity is perceived by consumers, the more favourable the attitude consumers have towards the brand-controlled communication.

H3. The more favourable the brand identity is perceived by consumers, the more favourable the attitude consumers have towards the brand-uncontrolled communication.

H4. The more favourable the brand strategy is perceived by consumers, the more favourable the attitude consumers have towards the brand-controlled communication.

H5. The more favourable the brand strategy is perceived by consumers, the more favourable the attitude consumers have towards the brand-uncontrolled communication.

\section{Controlled communication, uncontrolled communication, trust, loyalty and commitment}

Controlled and uncontrolled corporate communications are part of overall corporate communication. Both concepts are part of the company's management tools; all deliberately used forms of communication (internal and external) are consistently efficient and professional in generating a favourable basis for an association with a company's stakeholders (Van Rekom, 1997). A key element of controlled corporate communication is recognised as visual identity/design, which is a tangible centrepiece of the company's identity; it forms the physical symbols and produces physical recognition of the company (Olins, 1991). Nevertheless, the intangibility of brand exacerbates the effort of managing the visual identity of the company. For instance, logo, name and design all aim to transmit the tangible hints that influence consumers' perception. The organisation's design can be viewed as either long- or short-term commitment. Additionally, the visual identity/design components indicate the organisation's culture, which must be recognised by the organisation's stakeholders to make an impact on their trust, loyalty and commitment. A website is an essential communication function (Kim and Stoel, 2004) and is considered to be an organisation's virtual storefront (Argyriou et al., 2006). It provides general audience information about the firm and its products/services and promotes a positive corporate and product/brand image to improve trust, loyalty and commitment. Promotion is a kind of advertising of a product to endorse its effectiveness to deliver customers with different levels of hedonic benefits. Promotion is an opportunity for exploration, value expression and practical benefits such as improving shopping convenience, savings and higher product quality (Chandon et al., 2000). Promotion as a key element of controlled communication provides recognisability and evokes an emotional response towards the company.

Organisations have many ways of communicating to create the organisation's distinguishing features. Therefore, in addition to visual identity, website and promotion, managers use uncontrolled communication. The key elements of uncontrolled communication have been identified as either word-of-mouth (WOM) or tertiary communications, which is a message that is imparted about the organisation by third parties. WOM can affect consumers' perceptions and expectations during their search for information and the subsequent purchase process; also, it influences their attitude during the re-purchase evaluation of alternative brands. WOM can impact their decisions either positively or negatively. Public relations and media relations are the significant functions for the maintenance of relations with the company's public, and are relied on for success, legitimacy and growth (Broom, 2011). Public relations activities are focused on an 
organisation's familiarity and recognition rather than on individual promotions communicating a company's corporate/brand identity. However, media and public relation activities are gradually being recognised by the marketers as important components of the IMC arsenal; however, there is a lack of studies on public relations and marketing communication. Hallahan (2007, p. 308) states that the public relations literature recognises communication as "fragmentary and hardly conclusive". Grunig (2006) emphasised the association between IMC and public relations as an independent strategic function (Grunig, 2006). IMC can be perceived as a marketing planning process. However, IMC can trigger public relations' authors' doubts about marketing as the prevailing purpose of communication (Grunig et al., 2002) and public relations as a marketing support purpose (Debreceny and Cochrane, 2004; Hendrix, 2004; Keh et al., 2007).

Given the exceptional influence of social media, companies are increasingly trusting it as a channel for marketing communication (Kumar et al., 2016). Alden et al. (2011) found the best three IMC practices for social media marketing to be:

(1) the brand should be promoted consistently within different elements of the communication mix;

(2) the 4Ps should be integrated; and

(3) communication should provide information on positive social behaviour changes and actions.

Whereas commercial marketers mostly emphasise the first principle when they mention IMC, social media marketers consider the efficiency of their interventions and usually use all three tenets for planning an advertising campaign, and they refer to this as the ISMC (integrated social marketing communications) approach. ISMC scholars (Grier and Bryant, 2005; Maibach, 2002) refer to social marketing promotion as an integrated constituent of the social marketing endeavours. An original and creative programme can produce a higher level of customer attention. The social marketing and IMC relationship stresses the importance of integrating communications with elements of the communication mix (Deshpande et al., 2004; Smith, 2009). The internet is a significant medium and channel for marketing and is an important part of a firm's multichannel strategy (Bart et al., 2005). To exploit this channel effectively, firms need to create long-term relationships with customers. To cultivate relationships, customer trust is important (Dwyer et al., 1987; Shankar et al., 2003). Developing a successful marketing strategy would require an understanding of the way consumer trust is developed and how trust affects consumer behaviour (Bart et al., 2005). Alden et al. (2011) believe that by integrating the approach to social marketing, managers could deliver more consistency in the brand's promotional efforts through the communications mix; this results in synergy, which improves the influence on consumer trust, loyalty and commitment. Taken from the above, we postulate the following:

H6. The more favourable the brand's controlled communication is perceived by consumers, the more favourable the attitude consumers have towards the brand's uncontrolled communication.

H7. The more favourable the brand's controlled communication is perceived by consumers, the more favourable trust consumers have towards the company.

H8. The more favourable the brand's controlled communication is perceived by consumers, the more favourable loyalty consumers have towards the company. loyalty and commitment 
EJM

51,3

580

H9. The more favourable the brand's controlled communication is perceived by consumers, the more favourable commitment consumers have towards the company.

H10. The more favourable the brand's uncontrolled communication is perceived by consumers, the more favourable trust consumers have towards the company.

H11. The more favourable the brand's uncontrolled communication is perceived by consumers, the more favourable loyalty consumers have towards the company.

H12. The more favourable the brand's uncontrolled communication is perceived by consumers, the more favourable commitment consumers have towards the company.

\section{Trust, loyalty and commitment}

The relationships between trust, loyalty and commitment were based on the seminal paper by Morgan and Hunt (1994) on relationship marketing. The commitment/trust theory makes relationship marketing more effective because it inspires marketers to aim at:

preserving relationship investments by co-operating with exchange partners; resist attractive short-term alternatives in favour of the expected long-term benefits; and view potentially high-risk options as being prudent because of the belief that their partners will not act opportunistically (Mukherjee and Nath, 2007, p. 1176).

Trust is defined as a psychological state of accepting vulnerability by expecting positive behaviour and intention of others (Rousseau et al., 1998). Trust is the confidence about a website or social media as an element of uncontrollable communication to deliver according to the expectation, which is based on prior experience (Gefen, 2000). Trust can therefore moderate loyalty and strengthen customer commitment. Trust is an important aspect of building a long-term relationship with customers. In addition, trust can be linked to the perception of consumers about the ability to meet the customers' loyalty. Loyalty can be defined as:

a deeply held commitment to re-buy or re-patronise a preferred product or service consistently in the future, thereby causing repetitive same-brand set purchasing, despite situational influences and marketing efforts having the potential to cause switching behaviour (Chaudhuri and Holbrook, 2001, p. 82).

According to Ponsonby-Mccabe and Boyle (2006), the key issues which encourage the consumers to become loyal to the brand are:

- willingness to re-purchase over and over again; and

- the belief that the consumption experience is good value for the price paid (p. 180).

Well-designed communication can have an impact on trust and loyalty, and impact the commitment of stakeholders to an organisation. The interactions between the constructs draw customers into the centre of the company's networks (Rao et al., 2000) by increasing the salience of the organisation identity in the mind of consumers, and increasing the likelihood of their commitment. Based on all the different arguments presented by various scholars, such as Kitchen (2005) and Van Riel (1995), we offer trust, loyalty and commitment as consequences of communications.

Furthermore, customers who are loyal to the company are less likely to switch, and they make more purchases compared to non-loyal customers. Also, loyal consumers may be willing to pay more for services or products, because they perceive some distinctive value in 
the brand compared to its competitors (Reichheld, 1996). Studies show that satisfying customers is very significant for the success of any company; however, there is no guarantee that the satisfied customer will come back and repeat the purchase. In addition, loyalties can influence commitment to the brand, as commitment is a psychological brand attachment which leads a customer to a state of motivation (Eagly and Chaiken, 1995). The motivation produced by high levels of commitment which is behavioural and attitudinal can be assumed to replace the selective cognitive processing of information which filters out aspects threatening the customers' attitude. Thus, according to the commitment/trust theory, the discussion highlights the significance of trust, its ambiguous association with loyalty and commitment and lastly, the significance in the current context of the research, it is hypothesised that:

H13. The more favourable the trust is perceived by consumers, the more favourable loyalty consumers have towards the company.

H14. The more favourable the loyalty is perceived by consumers, the more favourable commitment consumers have towards the company.

\section{Methods}

The study's context and data collection

This paper examines the applicability of commitment/trust theory (Morgan and Hunt, 1994) and the results are based on data which are collected from a well-recognised retail store in London. The high-end retail stores in London have well-known brands and are destinations for tourists and non-tourist visitors. According to Dennis et al. (2014), the high-end store can influence consumers' perception associated with its brand identity. An exploratory study was conducted in this study to gain an in-depth understanding of the research questions in the retail industry. To develop an appropriate scale, we follow Churchill's (1979) procedures:

- to gain an in-depth understanding of the research area (Dacin and Brown, 2002);

- to understand the actual practice in the field to gauge whether the proposed research study is relevant; and

- to obtain insightful information and understand the proposed research questions, generate hypotheses and refine the measures for a questionnaire (Churchill, 1979).

Nine interviews were conducted with academics and experts. The data collected assisted the researchers to narrow the search from broad to more specific and concrete data. The main scale measurements were generated from the preliminary qualitative research and literature review. Afterwards, the list was checked for inter-judge reliability by five academics in the field of branding and marketing. They commented on the suitability of the items and checked the clarity of wording; their suggestions were then incorporated. Also, they were asked about the significance of each statement and to indicate which items should be retained (Lichtenstein et al., 1990).

Then, to examine the research's conceptual model, a pre-test was conducted among 45 academics and practitioners to examine the suitability, validity and freedom from error of the measures developed. All responses were measured using a seven-point Likert-type scale (from $1=$ strongly disagree to $7=$ strongly agree). At this stage, reliability as an essential condition of validity and exploratory factor analysis (EFA) were tested to identify any patterns in the data (De Vaus, 2002). The scales illustrated a high degree of reliability, with a Cronbach's alpha of 0.95 ; this is greater than 0.70 , which is appropriate for most research purposes (De Vaus, 2002; Hair et al., 2006; Nunnally, 1978). After the validation process (pre-test), the main data set was collected from a self-structured administered questionnaire. 
Based on the study by Dennis et al. (2014) to represent sample as practicable of shoppers in 51,3 the store, a usable sample of 347 internal and external stakeholders (employees and visitors to the store) was collected on various days and hours including weekdays and weekends over a two-month period. This includes 105 male and 242 female respondents (plus five other missing answers to the gender question). The distribution according to ethnic group was 25 per cent Asian, 18.7 per cent mixed/multiple ethnic groups, 17.3 per cent English/Welsh/ Scottish/Northern Irish, 14.7 per cent Mediterranean, 8.6 per cent Black/African/Caribbean and 15.3 per cent others. The respondents were mainly undergraduates (47.6) with an average age of 30 to 39 years (40.6) and 20 to 29 years old (27.7 per cent). Respondents were mainly students (44.7 per cent) or employees at the store (16.4 per cent). Table I provides further details on the sample frame.

\section{The survey measures}

The questionnaires contained measures based on previous research and qualitative study. There are seven main constructs in the current research: identity (CBI), strategy (STR),

\begin{tabular}{|c|c|c|}
\hline & Frequency & $(\%)$ \\
\hline \multicolumn{3}{|l|}{ Gender } \\
\hline Female & 242 & 69.7 \\
\hline Male & 105 & 30.3 \\
\hline \multicolumn{3}{|l|}{ Education } \\
\hline High school/Some colleges & 118 & 34.0 \\
\hline Undergraduate & 165 & 47.6 \\
\hline Postgraduate and above & 64 & 18.4 \\
\hline \multicolumn{3}{|l|}{ Occupation } \\
\hline Top executive or manager & 8 & 2.3 \\
\hline Owner of a company & 17 & 4.9 \\
\hline Lawyer, dentist or architect etc & 27 & 7.8 \\
\hline Office/clerical staffs & 35 & 10.1 \\
\hline Worker & 5 & 1.4 \\
\hline Craftsman & 8 & 2.3 \\
\hline Student & 155 & 44.7 \\
\hline Housewife & 35 & 10.1 \\
\hline Employee at the store & 57 & 16.4 \\
\hline Age & 57 & 16.4 \\
\hline 19 years old or less & 45 & 13.0 \\
\hline 20 to 29 years & 96 & 27.7 \\
\hline 30 to 39 years & 141 & 40.6 \\
\hline 40 to 49 years & 29 & 8.4 \\
\hline 50 to 59 years & 26 & 7.5 \\
\hline 60 years old or more & 10 & 2.9 \\
\hline \multicolumn{3}{|l|}{ Ethnic groups } \\
\hline English/Welsh/Scottish/Northern Irish/British & 60 & 17.3 \\
\hline Mixed/multiple ethnic groups & 65 & 18.7 \\
\hline Asian & 88 & 25.4 \\
\hline Black/African/Caribbean & 30 & 8.6 \\
\hline Mediterranean & 51 & 14.7 \\
\hline Other ethnic group & 53 & 15.3 \\
\hline
\end{tabular}

Table I.

Respondents characteristics 
controlled communication (CCC), uncontrolled communication (UCC), trust (CBT), loyalty (CBL) and commitment (CBC). Identity is defined as the characteristics, features, attributes or traits of an organisation that are recognised to be central, enduring and distinctive through a company's guidelines, personality and positioning (Balmer, 2001; He and Balmer, 2005; He and Mukherjee, 2009; Van Riel and Balmer, 1997). The company's guidelines were measured by using four items (philosophy, value, vision and mission). The variable "personality" was obtained based on previous conceptualisations (sincere, excited, competence, sophistication and rugged), in particular those described by Aaker (1997). Positioning was measured as the respondents' perception towards the companies' target market, competition, product category and brand promise.

Corporate strategy can be defined as the master plan of an organisation which circumscribes the company's services/products, its total objectives and the policies through which it competes in its specific marketplace (Melewar, 2003). The variable strategy was measured through three constructs:

(1) differentiation (customer focus, unique selling point, customer knowledge and customer satisfaction);

(2) social responsibility (social participation, ethical, honest and transparent); and

(3) governance (policy, procedures, standards, accountability and equality).

Appendix 2 illustrates the study constructs and scale items.

Controlled communication is the tool of management by means of which all consciously used forms of external and internal communication are harmonised successfully and professionally to generate a favourable basis for associations with the stakeholders upon whom the organisation is dependent (Melewar, 2003; Van Rekom, 1997). Controlled communication consists of three key elements:

(1) visual identity/design (logo, name, colour and design) (Foroudi et al., 2014);

(2) promotion (product launches, sponsorships, events and loyalty incentives); and

(3) website.

The measurement for website was based on previous studies (Alwi, 2009; Argyriou et al., 2006; Halliburton and Ziegfeld, 2009). Previous studies recognised antecedents of website design used here; these include navigation, design/layout/appearance, functionality and usability, customisation, security, availability and information.

Semi-/uncontrolled communication is defined as organisational communication by sending signals that are not created consciously or deliberately (Melewar, 2003), and it is measured by means of four elements:

(1) WOM (consumers, suppliers, business customers, investors);

(2) public relations (media engagement, content management, event management and industry awards);

(3) media relations (print media, electronic media, television and radio); and

(4) social media (marketing podcasts, blogs, social networking websites and search engine optimisation).

Trust can be defined as the reliability of a brand or the willingness of the average consumer to trust the brand's capability to achieve its stated function and develop a long-lasting relationship (Chaudhuri and Holbrook, 2001). It can be measured through reliability, social consciousness, familiarity and identification. In addition, based on the definition by loyalty and commitment

583 
Chaudhuri and Holbrook (2001), loyalty is the devotion that leads to greater market share when a similar brand is constantly purchased by specific customers. The loyalty is related to experience, credibility, trendiness and innovation. Commitment can be described as a psychological bond that characterises an individual's relationship with an organisation (Bateman et al., 2011) via four particulars: brand relevance, brand love, brand dominance and brand preference.

\section{Analyses and results}

The study followed a measure validation procedure through a two-step approach based on Anderson and Gerbing (1988). In the first stage of analysis, EFA was run to achieve the theoretically expected factor solutions (Hair et al., 2006). All the scales illustrated acceptable reliability (Cronbach's alpha $<0.931$ ) (Nunnally, 1978). Bartlett's test of sphericity showed the association between the measurement items to be higher than 0.3, and this is also appropriate for EFA (Hair et al., 2006). In addition, Kaiser-Meyer-Olkin's measure of sampling adequacy is 0.941 . This is greater than 0.6 , which suggests suitability for EFA; furthermore, the relationships between the items are statistically significant and provide a parsimonious set of factors (Tabachnick and Fidell, 2007). The results from descriptive statistics and correlation matrix for the constructs showed that the correlation between each pair of latent variables was significantly less than 1 (Appendix 2).

In the second stage of analysis, the analysis was run using AMOS 21 (analysis of moment structures) using the default method - maximum likelihood. In this stage, CFA (confirmatory factor analysis) was used to measure construct unidimensionality; the investigation of each item was internally consistent and confirmed the constructs on the basis of the measurement models (Gerbing and Anderson, 1988). Additionally, discriminant validity indicated that relationships between the research factors were less than the suggested value of 0.92 (Kline, 2005). In addition, the homogeneity of the construct was examined by convergent validity which was inspected on the basis of construct reliabilities (Anderson and Gerbing, 1988). AVE (average variance extracted) for each construct ranged from 0.503 to 0.818 . A good rule of thumb is that an AVE of 0.5 or higher indicates adequate convergent validity. Then, the analysis proceeded to "step-two approach" known as the structural model.

In this stage, the structural model fit was examined throughout goodness-of-fit indices (df - degrees of freedom, 5,043.695; RMSEA - root mean square error of approximation, 0.058; CFI - comparative fit index, 0.921; IFI - incremental fit index, 0.921; and TLI - TuckerLewis index, 0.917). The "favourable" fit values provide a satisfactory fit to the data and therefore indicate the unidimensionality of the measures (Anderson and Gerbing, 1988). Afterwards, the hierarchical linear regression analysis was used to test the research hypotheses. Given the directional nature of the research hypotheses, the examinations are all one-tailed.

Table II shows the final research model with structural path coefficients and $t$-values for each relationship and with squared multiple correlations $\left(R^{2}\right)$ for each endogenous construct. The H1, proposing the direct effect of identity on strategy $(H 1: \beta=0.652, t=8.880)$, was statistically supported. $H 2$ and $H 3$ address the impact of identity on controlled communication and uncontrolled communication $(\beta=0.332, t=4.628 ; \beta=0.406, t=3.451$ respectively), and the significant relationships were confirmed. The findings signify that the relationship between strategy and controlled communication $(H 4)$ was significant $(\beta=$ $0.691, t=7.025)$. With regard to the fifth research hypothesis (H5), the unexpected result shows the relationship between strategy and uncontrolled communication $(\beta=-0.200$, $t=-1.132$ ) was non-significant. $H 6, H 7, H 8$ and $H 9$ address the impact of controlled communication on uncontrolled communication, trust, loyalty and commitment $(H 6: \beta=$ 


\begin{tabular}{|c|c|c|c|c|c|c|c|c|}
\hline \multicolumn{4}{|c|}{ Hypotheses relationships } & \multirow{2}{*}{$\begin{array}{c}\text { Estimate } \\
0.652\end{array}$} & \multirow{2}{*}{$\frac{\mathrm{SE}}{0.073}$} & \multicolumn{2}{|l|}{$\mathrm{CR}$} & \multirow[b]{2}{*}{ Accepted } \\
\hline$H 1$ & Identity & $\rightarrow$ & Strategy & & & 8.880 & $* * *$ & \\
\hline$H 2$ & Identity & $\rightarrow$ & $\begin{array}{l}\text { Controlled corporate brand } \\
\text { communication }\end{array}$ & 0.332 & 0.072 & 4.628 & $* * *$ & Accepted \\
\hline$H 3$ & Identity & $\rightarrow$ & $\begin{array}{l}\text { Uncontrolled corporate brand } \\
\text { communication }\end{array}$ & 0.406 & 0.118 & 3.451 & $* * *$ & Accepted \\
\hline$H 4$ & Strategy & $\rightarrow$ & $\begin{array}{l}\text { Controlled corporate brand } \\
\text { communication }\end{array}$ & 0.691 & 0.098 & 7.025 & $* * *$ & Accepted \\
\hline H5 & Strategy & $\rightarrow$ & $\begin{array}{l}\text { Uncontrolled corporate brand } \\
\text { communication }\end{array}$ & -0.200 & 0.177 & -1.132 & 0.258 & Rejected \\
\hline H6 & $\begin{array}{l}\text { Controlled corporate brand } \\
\text { communication }\end{array}$ & $\rightarrow$ & $\begin{array}{l}\text { Uncontrolled corporate brand } \\
\text { communication }\end{array}$ & 0.783 & 0.259 & 3.018 & 0.003 & Accepted \\
\hline$H 7$ & $\begin{array}{l}\text { Controlled corporate brand } \\
\text { communication }\end{array}$ & $\rightarrow$ & Trust & 0.643 & 0.221 & 2.916 & 0.004 & Accepted \\
\hline H8 & $\begin{array}{l}\text { Controlled corporate brand } \\
\text { communication }\end{array}$ & $\rightarrow$ & Loyalty & 1.722 & 0.332 & 5.187 & $* * *$ & Accepted \\
\hline H9 & $\begin{array}{l}\text { Controlled corporate brand } \\
\text { communication }\end{array}$ & $\rightarrow$ & Commitment & 0.580 & 0.173 & 3.359 & $* * *$ & Accepted \\
\hline H1O & $\begin{array}{l}\text { Uncontrolled corporate brand } \\
\text { communication }\end{array}$ & $\rightarrow$ & Trust & -0.344 & 0.201 & -1.710 & 0.087 & Rejected \\
\hline H11 & $\begin{array}{l}\text { Uncontrolled corporate brand } \\
\text { communication }\end{array}$ & $\rightarrow$ & Loyalty & -0.899 & 0.273 & -3.293 & $* * *$ & Accepted \\
\hline H12 & $\begin{array}{l}\text { Uncontrolled corporate brand } \\
\text { communication }\end{array}$ & $\rightarrow$ & Commitment & -0.262 & 0.177 & -1.484 & 0.138 & Rejected \\
\hline$H 13$ & Trust & & Loyalty & 0.145 & 0.060 & 2.424 & 0.015 & Accepted \\
\hline H14 & Loyalty & & Commitment & 0.149 & 0.096 & 1.547 & 0.122 & Rejected \\
\hline
\end{tabular}

Note: $* * * p<0.001$

\section{Trust, loyalty and commitment}

585

Table II.

Hypotheses summary

$0.783, t=3.018 ; H 7: \beta=0.643, t=2.916 ; H 8: \beta=1.722, t=5.187 ; H 9: \beta=0.580, t=3.359$ respectively) and the significant relationships were confirmed. The standardised regression path between uncontrolled communication and trust $(H 10: \beta=-0.344, t=-1.710, p=$ $0.087>0.05)$ and uncontrolled communication and commitment $(H 12: \beta=-0.262, t=$ $-1.484, p=0.138>0.05$ ) were rejected because the results were not statistically significant. As a result, it may be a challenge for companies to design a favourable uncontrolled communication which could influence the stakeholders' trust and commitment towards the organisations. H11, which explains the relationship between uncontrolled communication and loyalty, was found to be significant in the hypothesised direction $(\beta=-0.899, t=$ $-3.293)$. In the hypothesised model, the effect of trust on loyalty $(H 13: \beta=2.424, t=0.015)$ did reach significance. However, the results indicate that there are no relationships between loyalty and commitment $(\beta=0.149, t=1.547 p=0.122>0.05)$. The results show that the hypotheses received a considerable amount of support; 10 out of 14 relationships were statistically significant. The results of the validated structural model are depicted in Figure 2.

\section{Findings and discussion}

This paper contributes to several different research streams. By implicating identity and strategy as key drivers of IMCs, this research complements that built on consumers' trust, loyalty and commitment. The research's conceptual framework was developed based on commitment/trust theory and the understanding and application of IMC as synergy in communication, by using multiple modes of communication to send the desired message to the intended audiences and improve consumers' loyalty. The emphasis on identity and 


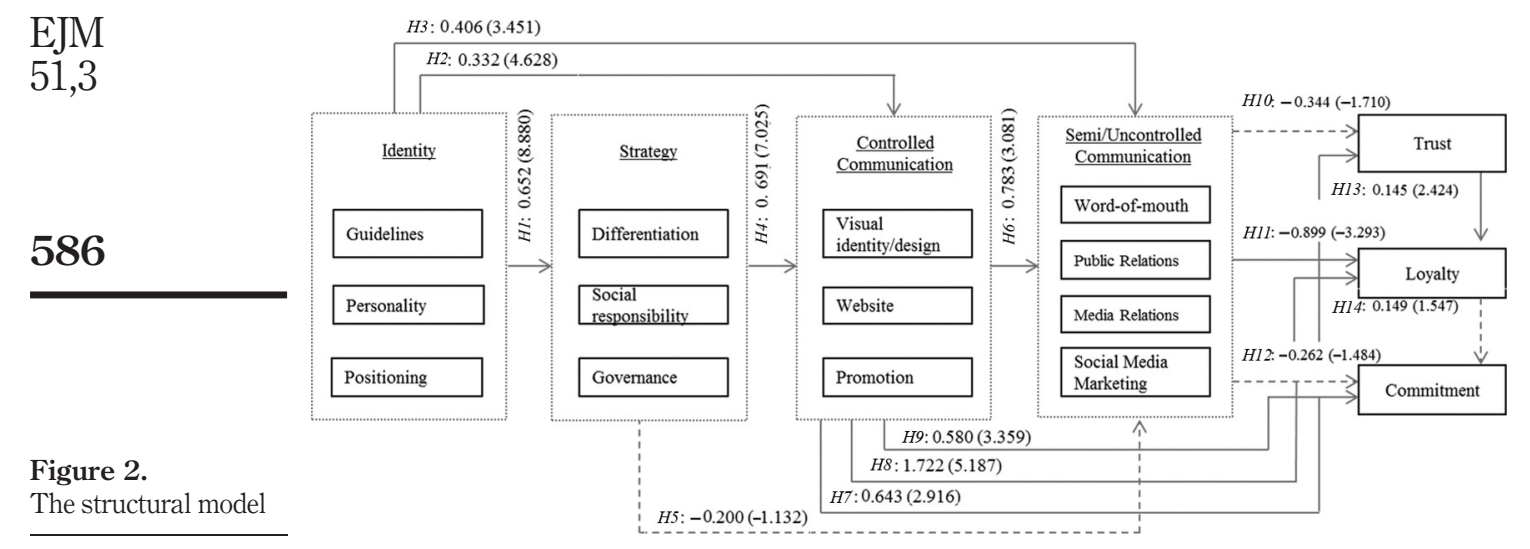

strategy enables the marketing managers to precisely and consistently communicate, develop and implement the IMC strategy. The results of this study and our framework can be a useful guideline for managers to create a more synergistic and effective IMC program.

The findings suggest that the elements of identity (guidelines, personality and positioning) have an influence on the strategy of the brand (brand identity has positive impacts on brand's strategy), which leads to a more synergistic and effective controlled and uncontrolled communication programme (identity has positive impacts on brand's controlled and uncontrolled communication). From an academic and industry standpoint, the study provides some support for confirming an idea that some marketing and communications practitioners have believed for years: that consumer attitudes towards a brand identity may be enhanced by pursuing a strategy that consistently integrates messages across controlled communication. This research makes a number of contributions to the literature of identity, strategy, communication and IMC. The research is the primary basis that confirms the presence of significant direct effects of both identity and strategy on IMC. This research offers managerial contributions for decision-makers, marketers and graphic designers who wish to understand the whole situation of the relationship between identity, strategy and favourable IMC, and their impact on consumers' trust, loyalty and commitment. Importantly, this study helps consultants and managers to understand whether the company's identity and strategy communicate an authentic message and the personality of the company to the target audience.

The next findings were based on the relationships between strategy and controlled and uncontrolled communication. The characteristics of strategy include differentiation, social responsibility and governance. Our study found that brand strategy has positive impacts on brand's visual identity/design, website and promotion (controlled communication). However, surprisingly, there was no relationship between brand's strategy and uncontrolled communication, and the regression path unexpectedly illustrated a significant negative relationship between these two variables $(\gamma=-0.200, t$-value $=-1.132)$. Therefore, $H 5$ was rejected because it was not statistically significant ( $\phi 0.258$ ). This unexpected result could be related to the industry type of the case company. For a more critical consideration of the emerging insignificant relationship, the literature and the qualitative data were revisited. The structural model assessment supported the discriminant validity of the research constructs, and established that the constructs measures are truly distinct. The assessed discriminant validity correlations were statistically significant $(\phi<0.05)$ (Hair et al., 2006). The estimated correlations among factors were less than the recommended value of 0.92 
(Kline, 2005). Because no study has examined IMC in terms of its association with brand/ corporate identity and strategy, as the current study has done, no direct comparison with previous research can be made.

Our conceptual framework has many implications for practitioners. The results show that the companies should focus on efforts that define and develop a favourable identity, and based on their identity, create a strategy to gain momentum. Following this, the managers and employees of the company should focus on communicating that provide consistent identity and strategy to all controlled communication tools. For instance, the company's visual identity such as its logo should be used consistently in any communication cues such as the company's website. The company should communicate the same message through all their communications to internal and external audiences. The key elements of uncontrolled communication have been identified as tertiary communications which are messages that are imparted about the organisation from third parties. Companies have less control over these communication cues which may influence decisions either positively or negatively. Managers should consider wide-ranging plans that assess the strategic roles of a diversity of communication disciplines and combine these disciplines to provide consistency, clarity and maximum communications influence (Schultz and Kitchen, 1997, p. 9). In any event, the findings of this study suggest that the need for further research into the reason why a brand's strategy did not appear to correlate with the uncontrolled communications concept.

Specific to IMC in the retail industry, the results of this study indicate that as companies have control of their brand's visual identity, website and promotion, the brand's controlled communication has positive impacts on uncontrolled communication. In addition, the results show that consumers' perception towards controlled communication has positive impacts on their trust, loyalty and commitment. Technology makes integration possible, and IMC programmes need to be adopted by organisations to generate synergy between the different marketing elements to attain short- and long-term relationships with consumers. Managers and practitioners should use a diversity of communication channels to maintain and enhance their relationships with consumers. In addition, managers should focus on developing relations between the brand and consumers through a component of IMC. In particular, retail communication and managers and sector brands should always rely on the company itself to represent the services and products, as well as consumer perception, which has implications for the company's success.

This article has also focused on the concepts of controlled communication and uncontrolled communication, their implementations and their relation to trust, loyalty and commitment. The study into past research has shown that while practitioners have indicated that IMC is required from organisations, little study has been carried out regarding their consequences to trust, loyalty and commitment, especially in the retail setting.

The next fundamental outcome of this study is that such an IMC programme will lead to stronger brand loyalty. The more positive and synergistic are controlled communication (brand's visual identity/design, website and promotion) and uncontrolled communication, the more effective will be the IMC programme, resulting in exceptionally superior brand loyalty. Every individual in the company is responsible for the firm's marketing communication efforts. The evidence of this study should be of interest to both proponents and critics of IMC and it is hoped that it will serve as an additional catalyst for further work in this area. There is little doubt that IMC is increasingly significant in the twenty-first century. However, the results show that the relationship between the uncontrolled communication and consumers' trust and commitment was not significant. This can confirm the essential tenet of the commitment/ trust theory. $H 10$ (H1O: $\beta=-0.344, t=-1.710, p=0.087>0.05)$ and H12 (H12: 
$\beta=-0.262, t=-1.484, p=0.138>0.05)$ were rejected, as they were not significantly different from 0 at the 0.001 level of probability.

With regard to the tenth research hypothesis (H1O) (brand's uncontrolled communication has a positive impact on consumers' trust towards the brand), the examination found that there is insignificant relationship between the consumer's attitude towards the brand's uncontrolled communication and their trust towards the brand. This finding is surprising, considering that the literature indicates that uncontrolled communication has an impact on consumers' perception but not necessarily an impact on consumers' trust and commitment; it can be a challenge for companies to increase their consumers' trust and commitment with the company and its services. Therefore, managers should pay particular attention to IMC information from the consumers' point of view.

\section{Future research}

This study attempts to develop understanding of the role of identity and strategy on IMC in relation to building trust, loyalty and commitment, although the findings are not without their limitations. This study provides a broad base for further research on IMC, identity, strategy and marketing channel evaluation and effectiveness at a time when this is a key issue for marketing communications.

In future research, the number of channels studied could be extended; indeed, there may well be new ones soon. In addition, this study used multiple constructs and measurements and worked within a retail setting in the UK. Researchers who study retail in the UK could explore these validated and reliable measurements. This research represents a first attempt to conceptualise the favourable IMC and its antecedents and consequences in a retail setting; hence, a future study could further develop the concept of IMC in a retail setting taking into account the various stakeholders (e.g. consumers, employees, shareholders and employers). It should also be helpful to consider other modes of services. In this respect, further study should investigate whether the domain of the favourable IMC construct modifies or changes, and how the association in the proposed framework would differ with the type of relationships being investigated. Furthermore, a future study could explore whether the relationships found in this study hold in other countries. This study is the first on the topic of the relationship identity and strategy on IMC in relation to building trust, loyalty and commitment. It attempts to empirically examine the IMC by using a quantitative approach to examine and validate a conceptual model using structural equation modelling. Given the increased attention on the IMC, the lack of systematic and empirical research on the IMC is alarming.

This study might be examined by conducting an exploratory research. Furthermore, replicated study is required to gain greater generalisability and validity for the examined measurement and relationships. In addition, the developed and extended scales of the favourable IMC and the related research constructs could be investigated in future research. Future research could replicate the conceptual framework of the present study in another setting. Furthermore, to adapt the constructs used in the current conceptual framework for a different research setting, future study should examine the validity and reliability of the constructs of interest. Because some of the findings of this study, such as the direct effect of strategy on uncontrolled communication, were unexpected and could be related to the type of business that the case company belongs to, future study might usefully repeat this research in another sector or country, to examine the abstractions of the findings. Furthermore, the relationship between the uncontrolled communication and trust and commitment was not found to be significant. This could be a long-term investigation. 


\section{References}

Aaker, J.L. (1997), "Dimensions of brand personality”, Journal of Marketing Research, Vol. 34 No. 3, pp. 347-356.

Aaker, D.A. and Joachimsthaler, E. (2012), Brand Leadership, Simon and Schuster.

Abratt, R. (1989), "A new approach to the corporate image management process", Journal of Marketing Management, Vol. 5 No. 1, pp. 63-76.

Aghion, P., Dewatripont, M. and Rey, P. (1997), "Corporate governance, competition policy and industrial policy”, European Economic Review, Vol. 41 No. 3, pp. 797-805.

Aguilera, R.V. and Jackson, G. (2003), "The cross-national diversity of corporate governance: dimensions and determinants", Academy of Management Review, Vol. 28 No. 3, pp. 447-465.

Alam, A., Usman Arshad, M. and Adnan Shabbir, S. (2012), "Brand credibility, customer loyalty and the role of religious orientation", Asia Pacific Journal of Marketing and Logistics, Vol. 24 No. 4, pp. 583-598.

Albert, S. and Whetten, D.A. (1985), “Organizational identity”, Research in Organizational Behavior, Vol. 7, pp. 263-295.

Alden, D., Basil, M. and Deshpande, S. (2011), "Communications in social marketing”, Sage Handbook on Social Marketing, Sage, Thousand Oaks, CA.

Alessandri, W.S. (2001), "Modeling corporate identity: a concept explication and theoretical explanation", Corporate Communications: An International Journal, Vol. 6 No. 4, pp. 173-182.

Alwi, S.F.S. (2009), "Online corporate brand images and consumer loyalty", International Journal of Business and Society, Vol. 10 No. 2, p. 1.

Alwi, S.F.S. and Kitchen, P.J. (2014), "Projecting corporate brand image and behavioral response in business schools: cognitive or affective brand attributes?", Journal of Business Research, Vol. 67 No. 11, pp. 2324-2336.

Anderson, E.W., Fornell, C. and Lehmann, D.R. (1994), "Customer satisfaction, market share, and profitability: findings from Sweden”, The Journal of Marketing, Vol. 58 No. 3, pp. 53-66.

Anderson, J.C. and Gerbing, D.W. (1988), "Structural equation modelling in practice: a review and recommended two-step approach”, Psychological Bulletin, Vol. 103 No. 3, pp. 411-423.

Argyriou, E., Kitchen, P.J. and Melewar, T.C. (2006), “The relationship between corporate websites and brand equity: a conceptual framework and research agenda", International Journal of Market Research, Vol. 48 No. 5, pp. 575-599.

Baker, M.J. (2014), Marketing Strategy and Management, Palgrave Macmillan.

Baker, W.E. and Sinkula, J.M. (1999), "The synergistic effect of market orientation and learning orientation on organizational performance", Journal of the Academy of Marketing Science, Vol. 27 No. 4, pp. 411-427.

Balmer, J.M.T. (1995), “Corporate branding and connoisseurship”, Journal of General Management, Vol. 21 No. 1, pp. $22-46$.

Balmer, J.M.T. (2001), "Corporate identity, corporate branding and corporate marketing seeing through the fog", European Journal of Marketing, Vol. 35 Nos 3/4, pp. 248-291.

Balmer, J.M.T. (2008), "Identity based views of the corporation: insights from corporate identity, organisational identity, social identity, visual identity, corporate brand identity and corporate image", European Journal of Marketing, Vol. 42 Nos 9/10, pp. 879-906.

Balmer, J.M.T. (2009), "Corporate marketing: apocalypse, advent and epiphany”, Management Decision, Vol. 47 No. 4, pp. 544-572.

Balmer, J.M.T. and Gray, E.R. (2003), “Corporate brands: what are they? What of them?”, European Journal of Marketing, Vol. 37 Nos 7/8, pp. 972-997.

Balmer, J.M.T. and Wilson, A. (1998), "Corporate identity: there is more to it than meets the eye", International Studies of Management and Organisation, Vol. 28 No. 3, pp. 12-31. 
Balmer, J.M.T., Fukukawa, K. and Grey, E. (2007), “The nature and management of ethical corporate identity: a commentary on corporate identity, corporate social responsibility and ethics", Journal of Business Ethics, Vol. 76 No. 1, pp. 7-15.

Balmer, J.M.T., Powell, S.M. and Greyser, S.A. (2011), "Explicating ethical corporate marketing. Insights from the BP Deepwater Horizon catastrophe: the ethical brand that exploded and then imploded", Journal of Business Ethics, Vol. 102 No. 1, p. 1.

Barich, H. and Kotler, P. (1991), "A framework for image management”, Sloan Management Review, Vol. 32 No. 2, pp. 4-104.

Bart, Y., Shankar, V., Sultan, F. and Urban, G.L. (2005), "Are the drivers and role of online trust the same for all web sites and consumers? A large-scale exploratory empirical study", Journal of Marketing, Vol. 69 No. 4, pp. 133-152.

Bateman, P.J., Gray, P.H. and Butler, B.S. (2011), "Research note-the impact of community commitment on participation in online communities", Information Systems Research, Vol. 22 No. 4, pp. 841-854.

Bauer, R., Guenster, N. and Otten, R. (2004), "Empirical evidence on corporate governance in Europe: the effect on stock returns, firm value and performance", Journal of Asset Management, Vol. 5 No. 2, pp. 91-104.

Belch, G.E. and Belch, M.A. (2011), Advertising and Promotion: An Integrated Marketing Communications Perspective, 9th ed., McGraw-Hill/Irwin, New York, NY.

Benston, G.J. (1982), "An analysis of the role of accounting standards for enhancing corporate governance and social responsibility", Journal of Accounting and Public Policy, Vol. 1 No. 1, pp. 5-17.

Bhattacharya, C.B. and Sen, S. (2003), "Consumer-company identification: a framework for understanding consumers, relationships with companies", Journal of Marketing, Vol. 67 No. 2, pp. 76-88.

Brinson, P. (2006), "Liberation frequency: the free radio movement and alternative strategies of media relations", The Sociological Quarterly, Vol. 47 No. 4, pp. 543-568.

Broom, G.M. (2011), Cutlip and Centre's Effective Public Relations, Prentice Hall, New York, NY.

Brown, T.J. and Dacin, P.A. (1997), "The company and the product: corporate associations and consumer product responses", Journal of Marketing, Vol. 61 No. 1, pp. 68-84.

Campbell, M.C. and Keller, K.L. (2003), "Brand familiarity and advertising repetition effects", Journal of Consumer Research, Vol. 30 No. 2, pp. 292-304.

Carroll, B.A. and Ahuvia, A.C. (2006), "Some antecedents and outcomes of brand love", Marketing Letters, Vol. 17 No. 2, pp. 79-89.

Castronovo, C. and Huang, L. (2012), "Social media in an alternative marketing communication model”, Journal of Marketing Development and Competitiveness, Vol. 6 No. 1, pp. 117-134.

Chandon, P., Wansink, B. and Laurent, G. (2000), "A benefit congruency framework of sales promotion effectiveness", Journal of Marketing, Vol. 64 No. 4, pp. 65-81.

Chaudhuri, A. and Holbrook, M.B. (2001), "The chain of effects from brand trust and brand affect to brand performance: the role of brand loyalty", Journal of Marketing, Vol. 65 No. 2, pp. 81-93.

Christiansen, T. and Tax, S.S. (2000), "Measuring word of mouth: the questions of who and when?", Journal of Marketing Communications, Vol. 6 No. 3, pp. 185-199.

Churchill, G.A. (1979), “A paradigm for developing better measures of marketing constructs”, Journal of Marketing Research, Vol. 16 No. 1, pp. 64-73.

Cian, L., and Cervai, S. (2014), "Under the reputation umbrella: an integrative and multidisciplinary review for corporate image, projected image, construed image, organizational identity, and organizational culture", Corporate Communications: An International Journal, Vol. 19 No. 2, pp. 182-199. 
Cornelissen, J. and Harris, P. (2001), "The corporate identity metaphor: perspectives, problems and prospects", Journal of Marketing Management, Vol. 17 Nos 1/2, pp. 49-71.

Crombie, N. (2008), “Corporate governance and accountability”, Pacific Accounting Review, Vol. 20 No. 1, pp. 77-79.

Dacin, P.A., and Brown, T.J. (2002), "Corporate identity and corporate associations: a framework for future research", Corporate Reputation Review, Vol. 5 Nos. 2-3, pp. 254-263.

Dahlsrud, A. (2008), "How corporate social responsibility is defined: an analysis of 37 definitions: corporate social responsibility and environmental management”, Vol. 15 No. 1, pp. 1-13.

Danaher, P.J. and Rossiter, J.R. (2011), "Comparing perceptions of marketing communication channels", European Journal of Marketing, Vol. 45 Nos 1/2, pp. 6-42.

Das, G. (2014), "Impacts of retail brand personality and self-congruity on store loyalty: the moderating role of gender", Journal of Retailing and Consumer Services, Vol. 21 No. 2, pp. 130-138.

Desai, K.K. and Ratneshwar, S. (2003), "Consumer perceptions of product variants positioned on atypical attributes", Journal of the Academy of Marketing Science, Vol. 31 No. 1, pp. 22-35.

De Vaus, D. (2002), Surveys in Social Research, Routledge, London.

Debreceny, P. and Cochrane, L. (2004), "Two disciplines on the same road", Advertising Age, Vol. 75 No. 45 .

Dennis, C., Brakus, J.J., Gupta, S. and Alamanos, E. (2014), “The effect of digital signage on shopper behavior: the role of the evoked experience", Journal of Business Research, Vol. 67 No. 11, pp. 2250-2257.

Deshpande, S., Rothschild, M.L. and Brooks, R. (2004), "New product development in social marketing”, Social Marketing Quarterly, Vol. 10, pp. 39-49.

Dwyer, F.R., Schurr, P.H. and Oh, S. (1987), "Developing buyer-seller relationships”, Journal of Marketing, Vol. 51 No. 3, pp. 11-27.

Eagly, A.H. and Chaiken, S. (1995), "Attitude strength, attitude structure, and resistance to change", Attitude Strength: Antecedents and Consequences, Vol. 4, pp. 413-432.

Eagle, L., Kitchen, P.J. and Bulmer, S. (2007), "Insights into interpreting integrated marketing communications: a two-nation qualitative comparison", European Journal of Marketing, Vol. 41 Nos 7/8, pp. 956-970.

Eid, M.I. (2011), "Determinants of e-commerce customer satisfaction, trust, and loyalty in Saudi Arabia", Journal of Electronic Commerce Research, Vol. 12 No. 1, pp. 78-93.

Foroudi, P., Melewar, T.C. and Gupta, S. (2014), "Linking corporate logo, corporate image, and reputation: an examination of consumer perceptions in the financial setting", Journal of Business Research, Vol. 67 No. 11, pp. 2269-2281.

Garriga, E. and Melé, D. (2013), "Corporate social responsibility theories: mapping the territory", Citation Classics from the Journal of Business Ethics, Springer, The Netherlands, pp. 69-96.

Gefen, D. (2000), "E-commerce: the role of familiarity and trust", Omega, Vol. 28 No. 6, pp. 725-737.

Gerbing, D.W. and Anderson, J.C. (1988), "An updated paradigm for scale development incorporating uni-dimensionality and its assessment", Journal of Marketing Research, Vol. 25 No. 2, pp. 186-192.

Giles, D.C. and Maltby, J. (2004), "The role of media figures in adolescent development: relations between autonomy, attachment, and interest in celebrities", Personality and Individual Differences, Vol. 36 No. 4, pp. 813-822.

Gilly, M.C. and Wolfinbarger, M. (1998), “Advertising's internal audience”,Journal of Marketing, Vol. 62 No. 1, pp. 69-88.

Giovanis, A.N. and Athanasopoulou, P. (2014), "Gaining customer loyalty in the e-tailing marketplace: the role of e-service quality, e-satisfaction and e-trust", International Journal of Technology Marketing, Vol. 9 No. 3, pp. 288-304. 
Gounaris, S.P. (2005), "Trust and commitment influences on customer retention: insights from business-to-business services", Journal of Business Research, Vol. 58 No. 2, pp. 126-140.

Grant, A.E., Guthrie, K.K. and Ball-Rokeach, S.J. (1991), "Television shopping a media system dependency perspective", Communication Research, Vol. 18 No. 6, pp. 773-798.

Grier, S. and Bryant, C.A. (2005), "Social marketing in public health", Annual Review of Public Health, Vol. 26 No. 1, pp. 319-339.

Grunig, J.E. (2006), "Furnishing the edifice: ongoing research on Public relations as a strategic management function", Journal of Public Relations Research, Vol. 18 No. 2, pp. 151-176.

Grunig, L.A., Grunig, J.E. and Dozier, D.M. (2002), Excellence in Public relations and Communication Management: A Study of Communication Management in Three Countries, Erlbaum Associates, Mahwah, NJ.

Gurau, C. (2008), "Integrated online marketing communication: implementation and management", Journal of Communication Management, Vol. 12 No. 2, pp. 169-184.

Hair, J.F., William, C.B., Barry, B., Rolph, J., Anderson, E. and Tatham, R.L. (2006), Multivariate Data Analysis, Pearson, New Jersey.

Hallahan, K. (2007), "Integrated communication: Implications for and beyond public relations excellence", in Toth, E.L. (Ed.), The Future of Excellence in Public Relations and Communication Management: Challenges to the Next Generation, Lawrence Eralbaum, Mahwah, NJ, pp. 299-337.

Halliburton, C. and Ziegfeld, A. (2009), "How do major European companies communicate their corporate identity across countries? An empirical investigation of corporate internet communications", Journal of Marketing Management, Vol. 25 Nos 9/10, pp. 909-925.

Haniffa, R.M. and Cooke, T.E. (2002), "Culture, corporate governance and disclosure in Malaysian corporations", Abacus, Vol. 38 No. 3, pp. 317-349.

Harrison-Walker, L.J. (2001), "The measurement of word-of-mouth communication and an investigation of service quality and customer commitment as potential antecedents", Journal of Service Research, Vol. 4 No. 1, pp. 60-75.

Hatch, M.J. and Schultz, M. (1997), "Relations between organizational culture, identity and image", European Journal of Marketing, Vol. 31 Nos 5/6, pp. 356-365.

Hatch, M.J. and Schultz, M. (2001), "Are the strategic stars aligned for your corporate brand”, Harvard Business Review, Vol. 69, pp. 128-134.

He, H.W. and Balmer, J.M.T. (2005), "The saliency and significance of generic identity: an explanatory study of UK building societies", International Journal of Bank Marketing, Vol. 23 No. 4, pp. 334-348.

He, H.W. and Mukherjee, A. (2009), "Corporate identity and consumer marketing: a process model and research agenda”, Journal of Marketing Communications, Vol. 15 No. 1, pp. 1-16.

Henderson, P.W. and Cote, J.A. (1998), "Guidelines for selecting or modifying logos", Journal of Marketing, Vol. 62 No. 2, pp. 14-30.

Hendrix, J.A. (2004), Public Relations Cases, Thomson/Wadsworth, Belmont, CA.

Hoffman, D.L. and Fodor, M. (2010), “Can you measure the ROI of your social media marketing?”, MIT Sloan Management Review, Vol. 52 No. 1, pp. 41-49.

Jewell, R.D. and Saenger, C. (2014), "Associative and dissociative comparative advertising strategies in broadening brand positioning”, Journal of Business Research, Vol. 67 No. 7, pp. 1559-1566.

Kaplan, R.S. and Norton, D.P. (2001), The Strategy-focused Organization: How Balanced Scorecard Companies Thrive in the New Business Environment, Harvard Business Press.

Keh, H.T. and Xie, Y. (2009), "Corporate reputation and customer behavioral intentions: the roles of trust, identification and commitment", Industrial Marketing Management, Vol. 38 No. 7, pp. 732-742. 
Keh, H.T., Nguyen, T.T. and Ng, H.P. (2007), "The effects of entrepreneurial orientation and marketing information on the performance of SMEs", Journal of Business Venturing, Vol. 22 No. 4, pp. 592-611.

Kerr, G., Schultz, D., Patti, C. and Kim, I. (2008), “An inside-out approach to IMC: an international analysis", International Journal of Advertising, Vol. 27, pp. 511-548.

Kim, J., Morris, J.D. and Swait, J. (2008), “Antecedents of true brand loyalty”, Journal of Advertising, Vol. 37 No. 2, pp. 99-117.

Kim, S. and Stoel, L. (2004), “Apparel retailers: website quality dimensions and satisfaction”, Journal of Retailing and Consumer Services, Vol. 11 No. 2, pp. 109-117.

Kitchen, P.J. (2005), “New paradigms - IMC - under fire”, Competitiveness Review, Vol. 15 No. 1, pp. $72-80$.

Kitchen, P.J. and Burgmann, I. (2010), Integrated Marketing Communication, John Wiley and Sons.

Kitchen, P.J., Brignell, J., Li, T. and Spickett, G. (2004), "The emergence of IMC: a theoretical perspective", Journal of Advertising Research, Vol. 44, pp. 19-30.

Kitchen, P.J., Kim, I. and Schultz, D.E. (2008), "Integrated marketing communications: practice leads theory", Journal of Advertising Research, Vol. 48 No. 4, pp. 531-546.

Kliatchko, C. (2008), "Revisiting the IMC construct: a revised definition and four pillars", International Journal of Advertising, Vol. 27 No. 1, pp. 133-160.

Kline, R.B. (2005), Principles and Practice of Structural Equation Modeling, Guildwood, New York, NY.

Komiak, S.Y. and Benbasat, I. (2006), "The effects of personalization and familiarity on trust and adoption of recommendation agents", MIS Quarterly, Vol. 30 No. 4, pp. 941-960.

Kotler, J.P. (2000), How to Create, Win and Dominate Market, The Free Press, New York, NY, pp. 18-151.

Kotler, P., Wong, V., Saunders, J. and Armstrong, G. (2005), Principles of Marketing, 4th ed., Pearson Education, Essex.

Kuang-Jung, C., Mei-Liang, C., Chu-Mei, L. and Chien-Jung, H. (2015), "Integrated marketing communication, collaborative marketing, and global brand building in Taiwan", International Journal of Organizational Innovation (Online), Vol. 7 No. 4, p. 99.

Kumar, A., Bezawada, R., Rishika, R., Janakiraman, R. and Kannan, P.K. (2016), "From social to sale: the effects of firm-generated content in social media on customer behavior", Journal of Marketing, Vol. 80 No. 1, pp. 7-25.

La Porta, R., Lopez-de-Silanes, F., Shleifer, A. and Vishny, R. (2000), "Investor protection and corporate governance”, Journal of Financial Economics, Vol. 58 No. 1, pp. 3-27.

Lau, G.T. and Ng, S. (2001), "Individual and situational factors influencing negative word-of-mouth behavior", Canadian Journal of Administrative Sciences/Revue Canadienne des Sciences de l'Administration, Vol. 18 No. 3, pp. 163-178.

Lee, D.J. and Sirgy, M.J. (2004), "Quality-of-life (QOL) marketing: proposed antecedents and consequences", Journal of Macromarketing, Vol. 24 No. 1, pp. 44-58.

Lichtenstein, D.R., Netemeyer, R.G. and Burton, S. (1990), "Distinguishing coupon proneness from value consciousness: an acquisition transaction utility theory perspective", Journal of Marketing, Vol. 54, pp. 54-67.

Low, G.S. (2000), "Correlates of integrated marketing communications", Journal of Advertising Research, Vol. 40 No. 3, pp. 27-39.

Luck, E. and Moffatt, J. (2009), "IMC: Has anything really changed? A new perspective on an old definition", Journal of Marketing Communication, Vol. 15 No. 5, pp. 311-325.

Lusch, R.F. and Vargo, S.L. (2014), Service-dominant Logic: Premises, Perspectives, Possibilities, Cambridge University Press, Cambridge.

McGrath, J.M. (2005), “A pilot study testing aspects of the integrated marketing communications concept", Journal of Marketing Communications, Vol. 11 No. 3, pp. 191-214. 
MacMillan, I.C. and McGrath, R.G. (1997), "Discovering new points of differentiation”, Harvard Business Review, Vol. 75, pp. 133-145.

Madhavaram, S., Badrinarayanan, V. and McDonald, R.E. (2005), "Integrated marketing communication (IMC) and brand identity as critical components of brand equity strategy: a conceptual framework and research propositions", Journal of Advertising, Vol. 34 No. 4, pp. $69-80$.

Maibach, E.W. (2002), "Explicating social marketing: What is it and what isn't it?", Social Marketing Quarterly, Vol. 8 No. 4, pp. 7-13.

Martínez, P. and del Bosque, I.R. (2013), "CSR and customer loyalty: the roles of trust, customer identification with the company and satisfaction", International Journal of Hospitality Management, Vol. 35, pp. 89-99.

Melewar, T.C. (2003), "Determinants of the corporate identity construct: a review of the literature", Journal of Marketing Communications, Vol. 9 No. 4, pp. 195-220.

Michaelidou, N., Siamagka, N.T. and Christodoulides, G. (2011), "Usage, barriers and measurement of social media marketing: an exploratory investigation of small and medium B2B brands", Industrial Marketing Management, Vol. 40 No. 7, pp. 1153-1159.

Misuraca, G., Broster, D. and Centeno, C. (2012), "Digital Europe 2030: designing scenarios for ICT in future governance and policy making”, Government Information Quarterly, Vol. 29 No. 1, pp. 121-131.

Mohr, L.A. and Webb, D.J. (2005), “The effects of corporate social responsibility and price on consumer responses", Journal of Consumer Affairs, Vol. 39 No. 1, pp. 121-147.

Moir, L. (2001), "What do we mean by corporate social responsibility?", Corporate Governance: The International Journal of Business in Society, Vol. 1 No. 2, pp. 16-22.

Morgan, R.M. and Hunt, S.D. (1994), "The commitment-trust theory of relationship marketing", The Journal of Marketing, Vol. 58 No. 3, pp. 20-38.

Morley, D. and Robins, K. (2002). Spaces of Identity: Global Media, Electronic Landscapes and Cultural Boundaries, Routledge.

Mukherjee, A. and Nath, P. (2007), "Role of electronic trust in online retailing: a re-examination of the commitment-trust theory”, European Journal of Marketing, Vol. 41 Nos 9/10, pp. 1173-1202.

Mulhern, F. (2009), "Integrated marketing communications: From media channels to digital connectivity”, Journal of Marketing Communications, Vol. 15 Nos 2/3, pp. 85-101.

Mullerat, R.M. (2006), "Corporate social responsibility and transparency”, Oil, Gas and Energy Law Journal (OGEL), Vol. 4 No. 1.

Nunnally, J.C. (1978), Psychometric Theory, McGraw-Hill, New York, NY.

Nwete, B. (2007), "Corporate social responsibility and transparency in the development of energy and mining projects in emerging markets: is some law the answer", German Law Journal, Vol. 8 No. 4.

Olins, W. (1991), Corporate Identity, Thames and Hudson, Toledo.

Ots, M., and Nyilasy, G. (2015), “Integrated Marketing Communications (IMC): why does it fail?”, Journal of Advertising Research, Vol. 55 No. 2, pp. 132-145.

Pagano, M. and Volpin, P.F. (2005), "The political economy of corporate governance”, The American Economic Review, Vol. 95 No. 4, pp. 1005-1030.

Phelps, J.E. and Johnson, E. (1996), "Entering the quagmire: examining the 'meaning' of integrated marketing communication", Journal of Marketing Communication, Vol. 2 No. 3, pp. 159-172.

Ponsonby-McCabe, S. and Boyle, E. (2006), "Understanding brands as experiential spaces: axiological implications for marketing strategists", Journal of Strategic Marketing, Vol. 14 No. 2, pp. 175-189.

Porter, M. and Kramer, M. (2006), "Estrategia y sociedad”, Harvard Business Review, Vol. 84 No. 12, pp. $42-56$. 
Punjaisri, K. and Wilson, A. (2007), "The role of internal branding in the delivery of employee brand promise", Journal of Brand Management, Vol. 15, No. 1, pp. 57-70.

Rao, H., Davis, G.F. and Ward, A. (2000), "Embeddedness, social identity and mobility: Why firms leave the NASDAQ and join the New York Stock Exchange”, Administrative Science Quarterly, Vol. 45 No. 2, pp. 268-292.

Reichheld, F.F. (Ed.). ( 1996), The Quest for Loyalty: Creating Value Through Partnership, Harvard Business Press.

Rousseau, D.M., Sitkin, S.B., Burt, R.S. and Camerer, C. (1998), "Not so different after all: a cross-discipline view of trust", Academy of Management Review, Vol. 23 No. 3, pp. 393-404.

Sagar, P. and Singla, A. (2004), "Trust and corporate social responsibility: Lessons from India", Journal of Communication Management, Vol. 8 No. 3, pp. 282-290.

Schmitt, B.H., Simonson, A. and Marcus, J. (1995), "Managing corporate image and identity", Long Range Planning, Vol. 28 No. 5, pp. 82-92.

Schmitz, J. (1997), "Structural relations, electronic media, and social change: the public electronic network and the homeless", Virtual Culture, Sage Publications, pp. 80-101.

Schultz, D.E. and Kitchen, P.J. (1997), "Integrated marketing communications in US advertising agencies: an exploratory study", Journal of Advertising Research, Vol. 37 No. 5, pp. 7-18.

Shankar, V., Smith, A.K. and Rangaswamy, A. (2003), "Customer satisfaction and loyalty in online and offline environments", International Journal of Research in Marketing, Vol. 20 No. 2, pp. 153-175.

Siau, K. and Shen, Z. (2003), "Building customer trust in mobile commerce", Communications of the ACM, Vol. 46 No. 4, pp. 91-94.

Simoes, C., Dibb, S. and Fisk, R. (2005), "Managing corporate identity: an internal perspective”, Journal of the Academy of Marketing Science, Vol. 3 No. 2, pp. 153-168.

Skumanich, S.A. and Kintsfather, D.P. (1998), "Individual media dependency relations within television shopping programming a causal model reviewed and revised", Communication Research, Vol. 25 No. 2, pp. 200-219.

Slater, S.F. and Olson, E.M. (2000), "Strategy type and performance: the influence of sales force management", Strategic Management Journal, Vol. 21 No. 8, pp. 813-829.

Smith, B. (2009), "The power of the product P, or why toothpaste is so important to behavior change", Social Marketing Quarterly, Vol. 15, pp. 98-106.

Solomon, J. (2007), Corporate Governance and Accountability, John Wiley and Sons.

Spicer, C.H. (1993), "Images of public relations in the print media", Journal of Public Relations Research, Vol. 5 No. 1, pp. $47-61$.

Stelzner, M.A. (2011), "Social media marketing industry report", Social Media Examiner, Vol. 41, pp. 1-10.

Stock, R.M., Six, B. and Zacharias, N.A. (2013), "Linking multiple layers of innovation-oriented corporate culture, product program innovativeness, and business performance: a contingency approach", Journal of the Academy of Marketing Science, Vol. 41 No. 3, pp. 283-299.

Strauß, S. (2010), "The limits of control-(Governmental) identity management from a privacy perspective", IFIP PrimeLife International Summer School on Privacy and Identity Management for Life, Springer, Berlin Heidelberg, pp. 206-218.

Stuart, H. (1999), "Towards a definitive model of the corporate identity management process", Corporate Communications: An International Journal, Vol. 4 No. 4, pp. 200-207.

Sweeney, J. and Swait, J. (2008), "The effects of brand credibility on customer loyalty", Journal of Retailing and Consumer Services, Vol. 15 No. 3, pp. 179-193.

Tabachnick, B.G. and Fidell, L.S. (2007), Using Multivariate Statistics, Allyn and Bacon, Boston, MA. 
Van Rekom, J. (1997), "Deriving an operational measure of corporate identity", European Journal of Marketing, Vol. 31 Nos 5/6, pp. 410-421.

Van Riel, C.B.M. (1995), Principles of Corporate Communication, Prentice Hall, London.

Van Riel, C.B.M. and Balmer, J.M.T. (1997), "Corporate identity, concept, its measurement and management", European Journal of Marketing, Vol. 31 Nos 5/6, pp. 340-355.

Watkins, B. (2014), "An integrated approach to sports branding: examining the influence of social media on brand outcomes", International Journal of Integrated Marketing Communications, Vol. 6 No. 2.

Weinberg, T. (2009). The New Community Rules: Marketing on the Social Web, O'Reilly Media.

Whiting, A. and Williams, D. (2013), "Why people use social media: a uses and gratifications approach", Qualitative Market Research: An International Journal, Vol. 16 No. 4, pp. 362-369.

$\mathrm{Xu}, \mathrm{M}$. and Walton, J. (2005), "Gaining customer knowledge through analytical CRM", Industrial Management and Data Systems, Vol. 105 No. 7, pp. 955-971.

Yeh, Y.P. (2015), “Corporate social responsibility and service innovation on customer loyalty: an empirical investigation in wealth management services", International Journal of Bank Marketing, Vol. 33 No. 6, pp. 823-839.

Zarrella, D. (2009), The Social Media Marketing Book, O'Reilly Media.

Zhang, S.S., van Doorn, J. and Leeflang, P.S. (2014), "Does the importance of value, brand and relationship equity for customer loyalty differ between Eastern and Western cultures?", International Business Review, Vol. 23 No. 1, pp. 284-292.

\section{Further reading}

Porcu, L., del Barrio-García, S. and Kitchen, P.J. (2012), "How Integrated Marketing Communications (IMC) works? A theoretical review and an analysis of its main drivers and effects/ $\not$ Cómo funciona la Comunicación Integrada de Marketing (CIM)? Una revisión teórica y un análisis de sus antecedentes y efectos", Comunicación y sociedad, Vol. 25 No. 1, p. 313.

\section{Corresponding author}

Pantea Foroudi can be contacted at: p.foroudi@mdx.ac.uk 


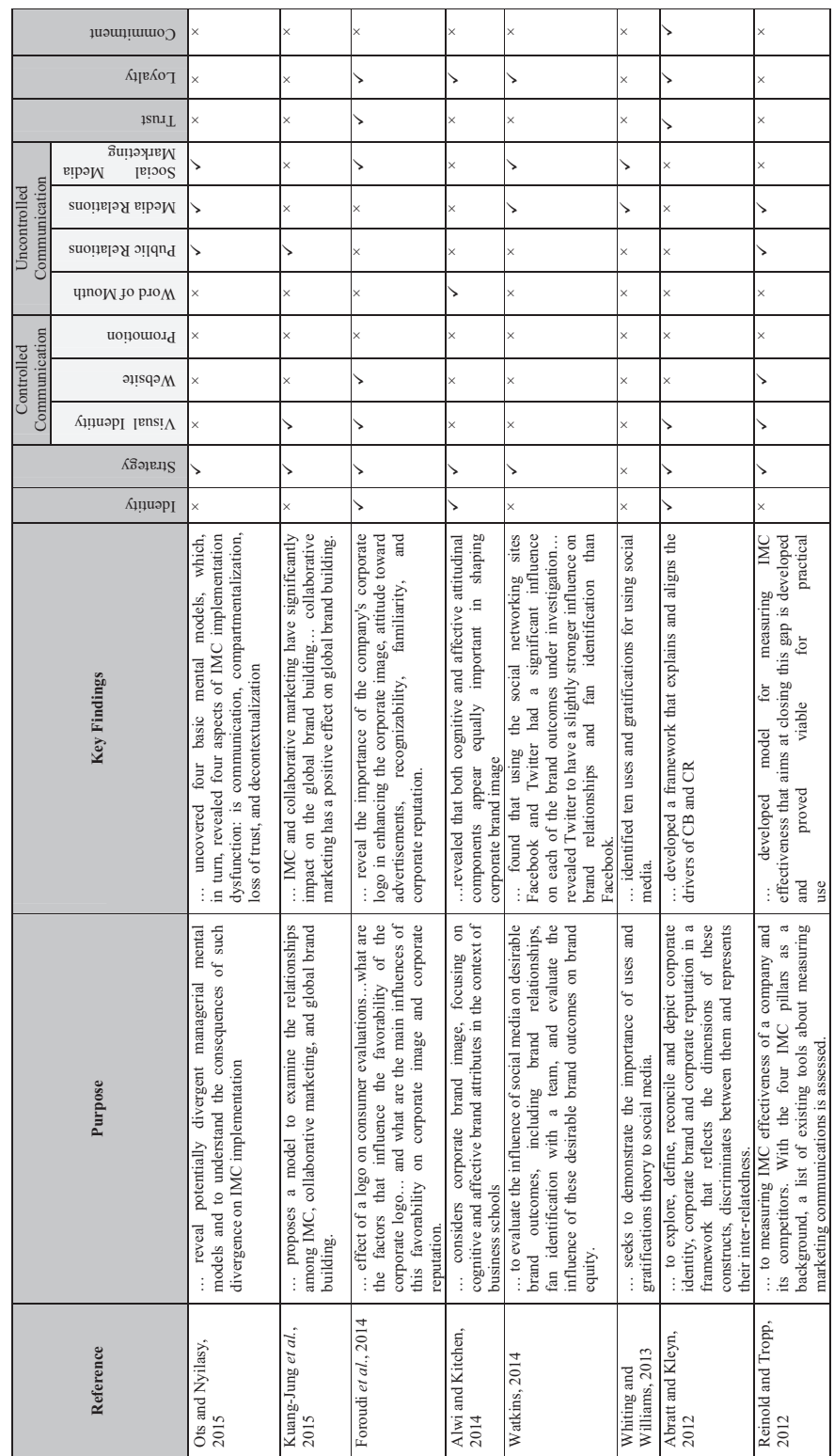

Figure AI.

The notion of integrating identity, strategy and communications for trust, loyalty and commitment from key authors 
EJM
51,3

598

Figure AI.

\begin{tabular}{|c|c|c|c|c|c|c|c|}
\hline$>$ & $\times$ & x & $\times$ & $\times$ & $\times$ & $\times$ & $\times$ \\
\hline$>$ & $x$ & $x$ & x & $>$ & x & x & $\times$ \\
\hline$>$ & $\times$ & $>$ & $\times$ & $x$ & $x$ & $x$ & $x$ \\
\hline$\times$ & $>$ & $>$ & $>$ & $\times$ & $>$ & $>$ & $\times$ \\
\hline$>$ & $>$ & $>$ & $>$ & $\times$ & $>$ & $>$ & $\times$ \\
\hline$\times$ & $>$ & $x$ & $x$ & $x$ & $\times$ & $x$ & $x$ \\
\hline$\times$ & $>$ & x & $x$ & $x$ & $x$ & $>$ & $x$ \\
\hline$\times$ & $>$ & $>$ & $>$ & $\times$ & $>$ & $>$ & $\times$ \\
\hline$>$ & $>$ & $\times$ & $\times$ & $>$ & $>$ & $x$ & $>$ \\
\hline$\times$ & $>$ & $\times$ & $\times$ & $\times$ & $\times$ & $\times$ & $>$ \\
\hline x & $\times$ & $\times$ & $>$ & $\times$ & $>$ & $>$ & $>$ \\
\hline$>$ & $>$ & $x$ & $x$ & $x$ & x & $>$ & $>$ \\
\hline 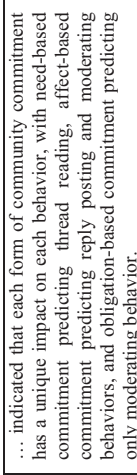 & 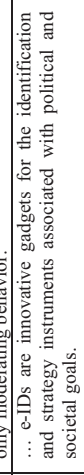 & 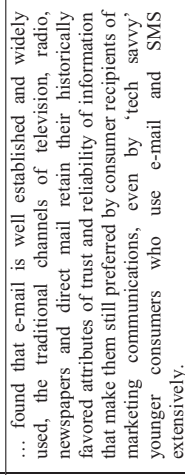 & 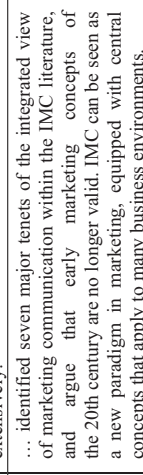 & 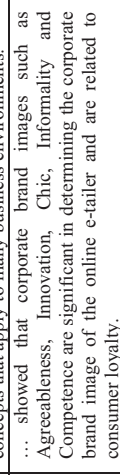 & 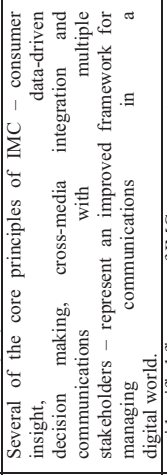 & 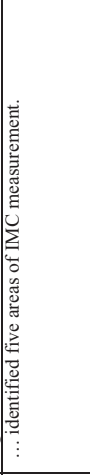 & 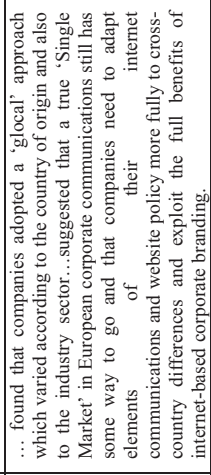 \\
\hline 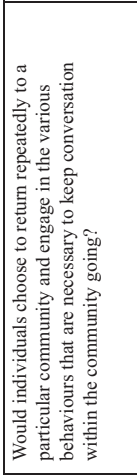 & 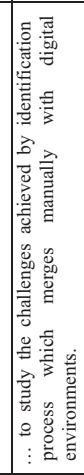 & 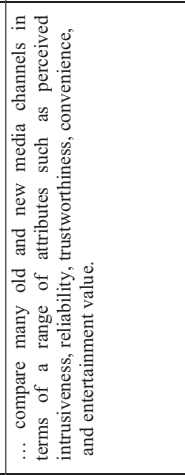 & 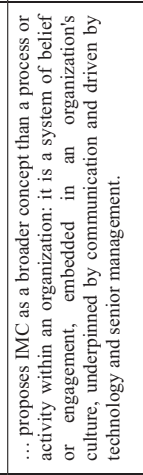 & 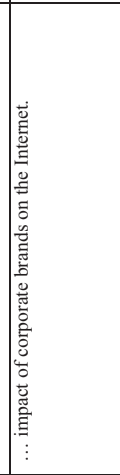 & 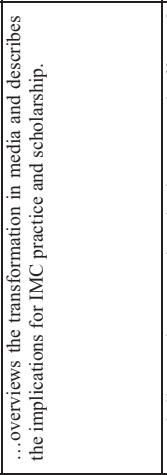 & 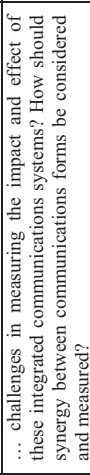 & 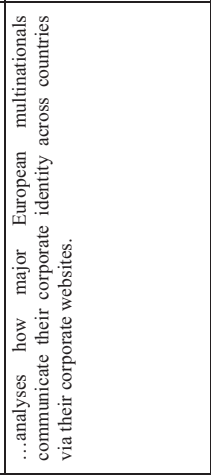 \\
\hline 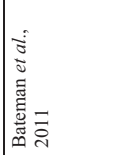 & 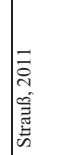 & 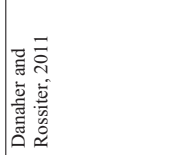 & 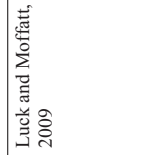 & 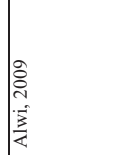 & 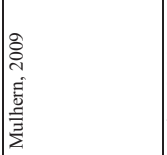 & & 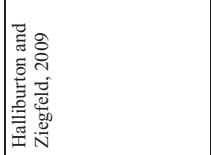 \\
\hline
\end{tabular}




\begin{tabular}{|c|c|c|c|c|c|c|c|c|c|}
\hline$\times$ & $\times$ & $x$ & $>$ & $>$ & $\times$ & $x$ & $x$ & $x$ & $x$ \\
\hline$x$ & $\times$ & $>$ & $\times$ & $>$ & $x$ & $\times$ & $x$ & $x$ & $x$ \\
\hline$x$ & $\times$ & $>$ & $x$ & $>$ & $>$ & $x$ & $x$ & $x$ & $>$ \\
\hline$>$ & $x$ & $>$ & $>$ & $>$ & $>$ & $>$ & $>$ & $>$ & $\times$ \\
\hline$>$ & $>$ & $>$ & $>$ & $>$ & $>$ & $>$ & $>$ & $>$ & $x$ \\
\hline$x$ & $x$ & $x$ & $>$ & $>$ & $>$ & $>$ & $\times$ & \rangle & $\times$ \\
\hline$\times$ & $\times$ & $\times$ & $\times$ & $>$ & $\times$ & $\times$ & $x$ & $x$ & $x$ \\
\hline$>$ & $>$ & $x$ & $>$ & $\times$ & $>$ & $\times$ & $>$ & $>$ & $x$ \\
\hline x & x & $x$ & $x$ & $>$ & $>$ & $x$ & $x$ & $\times$ & $>$ \\
\hline$x$ & $\times$ & $\times$ & $x$ & $\times$ & $>$ & $x$ & $>$ & $\times$ & $x$ \\
\hline$>$ & $>$ & $\times$ & $>$ & $\times$ & $>$ & $>$ & $>$ & $>$ & $>$ \\
\hline$>$ & $x$ & $>$ & $\times$ & $\times$ & $>$ & $>$ & $x$ & $>$ & $x$ \\
\hline 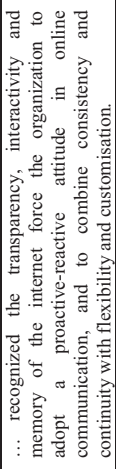 & 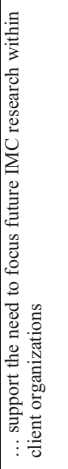 & 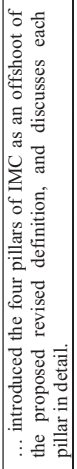 & 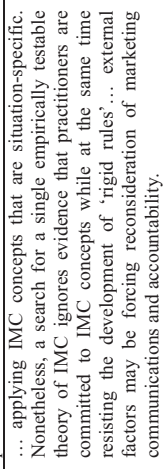 & 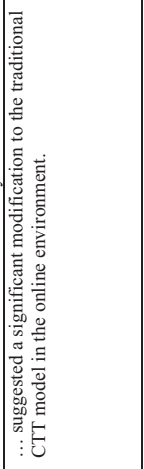 & 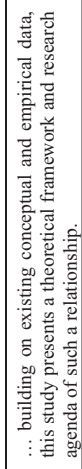 & 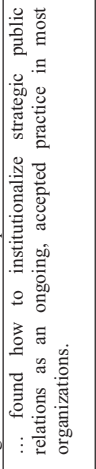 & 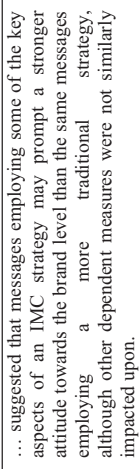 & 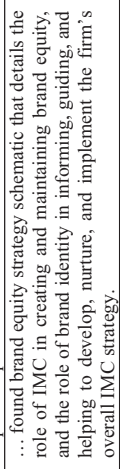 & 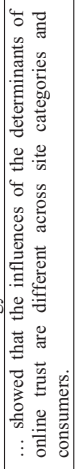 \\
\hline 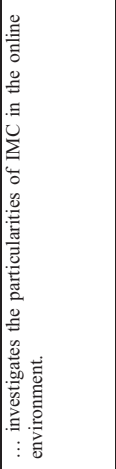 & 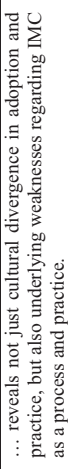 & 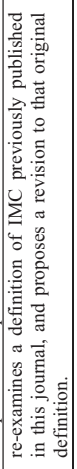 & 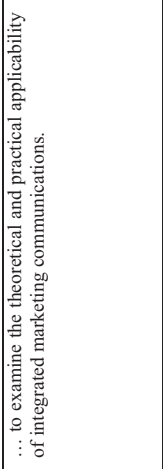 & 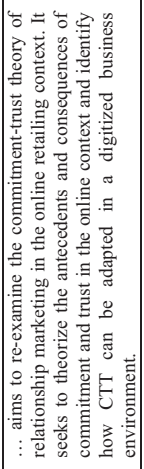 & 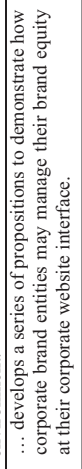 & 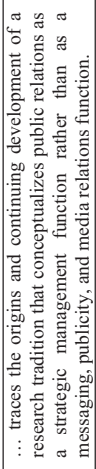 & 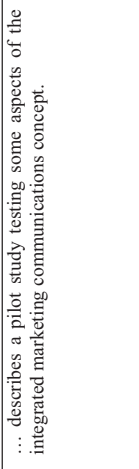 & 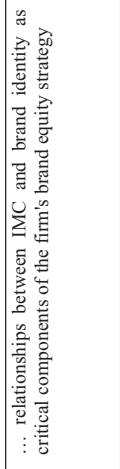 & 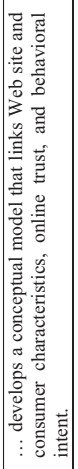 \\
\hline 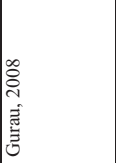 & 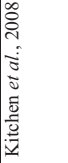 & 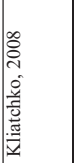 & 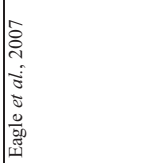 & 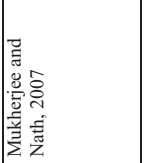 & 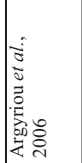 & 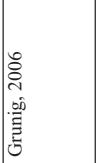 & 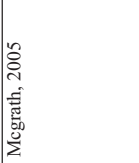 & 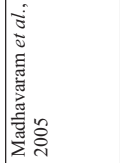 & 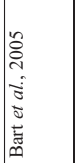 \\
\hline
\end{tabular}

Trust, loyalty and commitment

599

Figure AI. 
EJM

51,3

600

\begin{tabular}{|c|c|c|c|c|c|c|c|}
\hline x & $\times$ & $\times$ & $>$ & $\times$ & $>$ & $>$ & $>$ \\
\hline x & $\times$ & $x$ & $>$ & $x$ & $>$ & $\times$ & $>$ \\
\hline x & $\times$ & $>$ & $>$ & $x$ & $>$ & $>$ & $>$ \\
\hline$>$ & $>$ & $\times$ & $\times$ & $\times$ & $\times$ & $>$ & $\times$ \\
\hline x & $>$ & $\times$ & $x$ & $>$ & $x$ & $\times$ & $\times$ \\
\hline$x$ & $>$ & $x$ & $x$ & $x$ & $\times$ & $\times$ & $x$ \\
\hline x & $\times$ & $x$ & $\times$ & $x$ & $\times$ & $x$ & $\times$ \\
\hline$x$ & $>$ & $x$ & $\times$ & $x$ & $x$ & $\times$ & $\times$ \\
\hline x & $\times$ & $>$ & $\times$ & $x$ & $\times$ & $\times$ & $\times$ \\
\hline x & $x$ & $>$ & $\times$ & $>$ & $x$ & $x$ & $\times$ \\
\hline$>$ & $\times$ & $x$ & $>$ & $>$ & $\times$ & $\times$ & $>$ \\
\hline$\times$ & $x$ & $x$ & $>$ & $>$ & $x$ & $x$ & $>$ \\
\hline 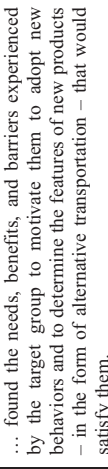 & 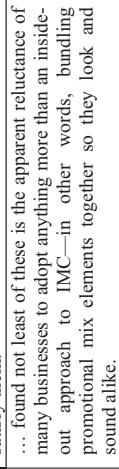 & 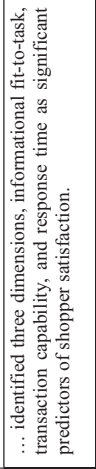 & 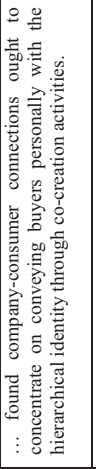 & 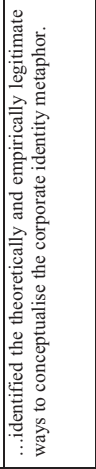 & 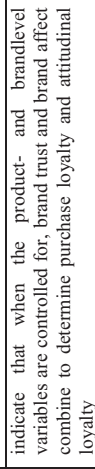 & 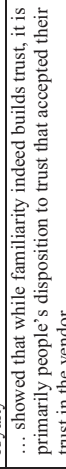 & 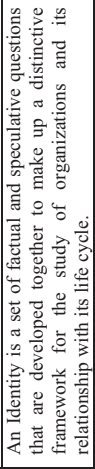 \\
\hline 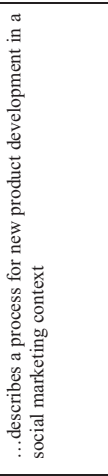 & 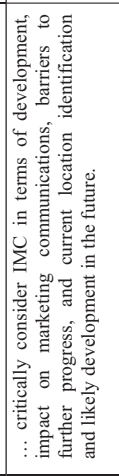 & 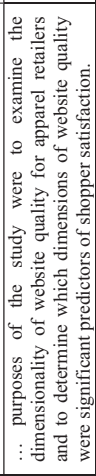 & 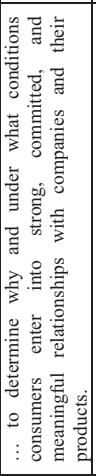 & 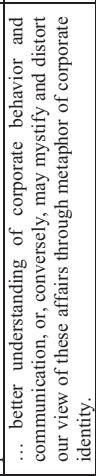 & 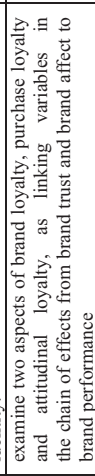 & 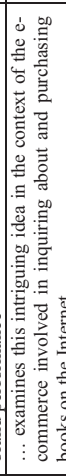 & 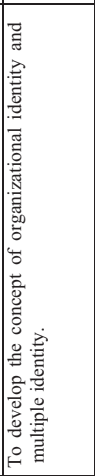 \\
\hline 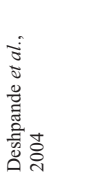 & 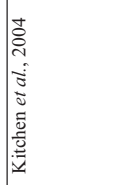 & 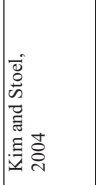 & 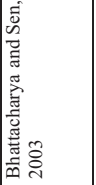 & 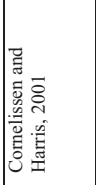 & 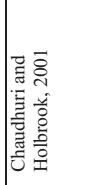 & 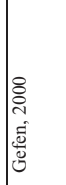 & 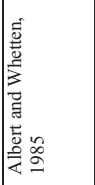 \\
\hline
\end{tabular}

Figure AI. 


\section{Appendix 2}

Trust, loyalty and

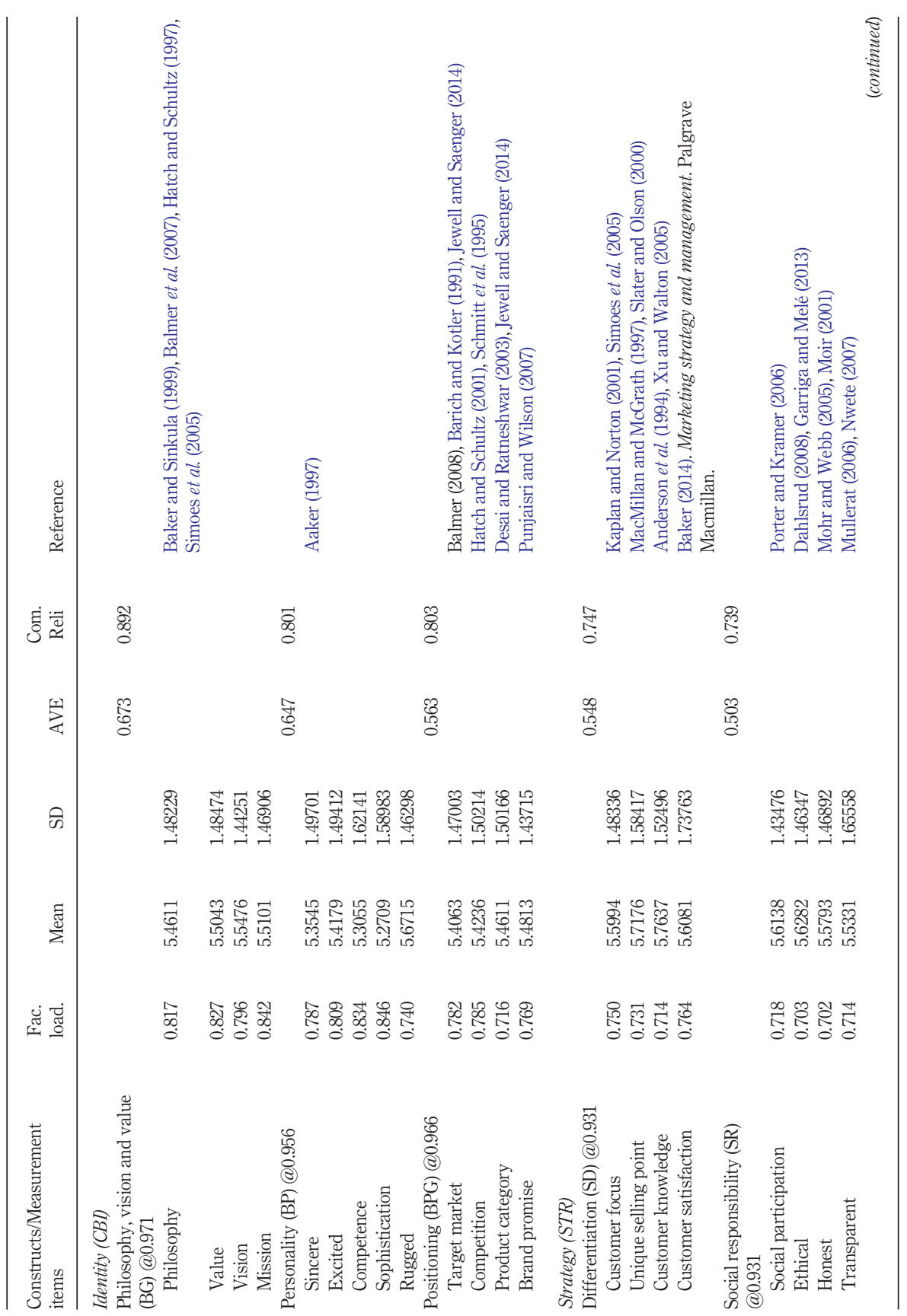

Table AI.

Study constructs and scale items, descriptive statistics, factor loadings and reliabilities 
EJM
51,3

602

Table AI.

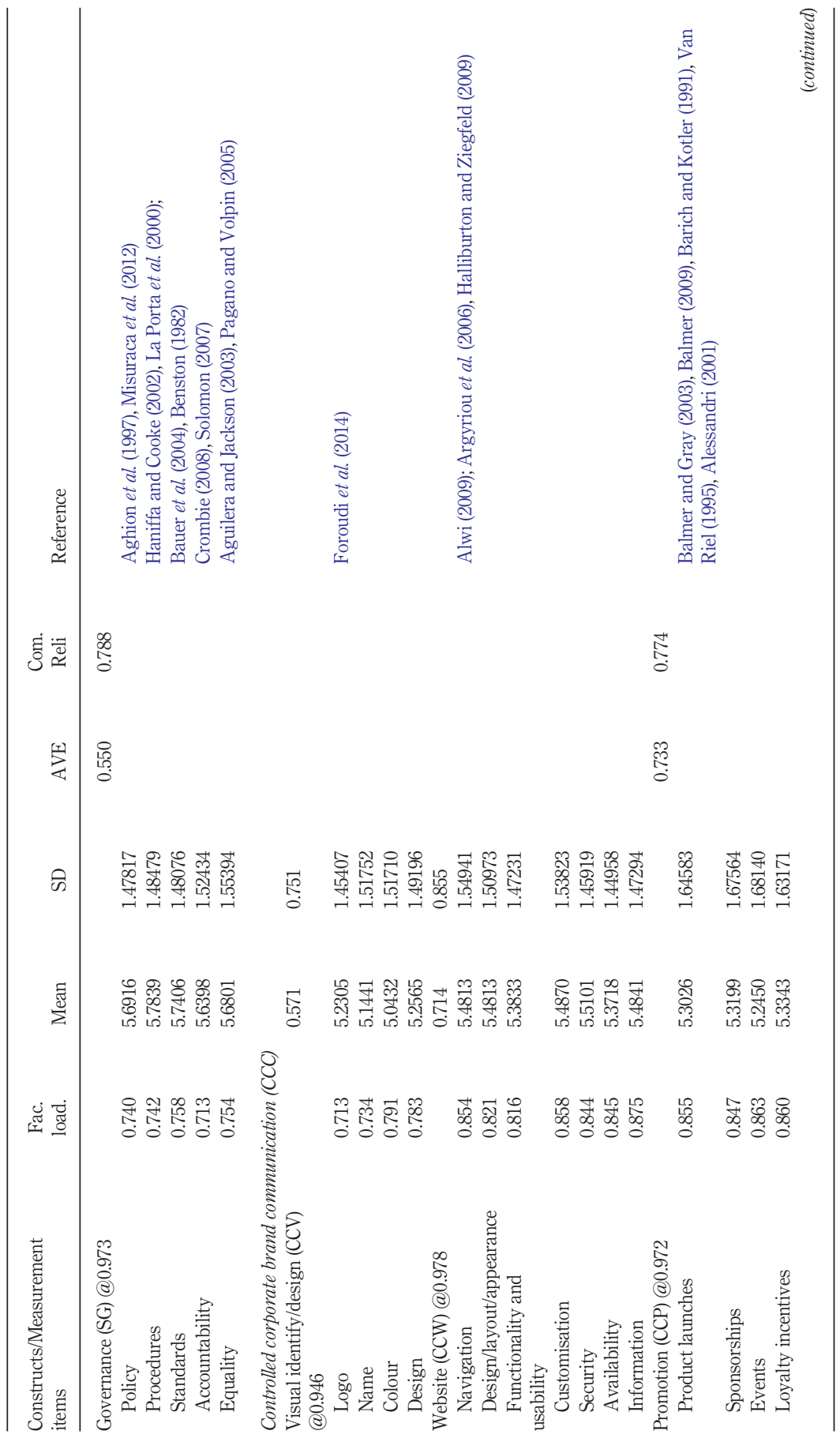




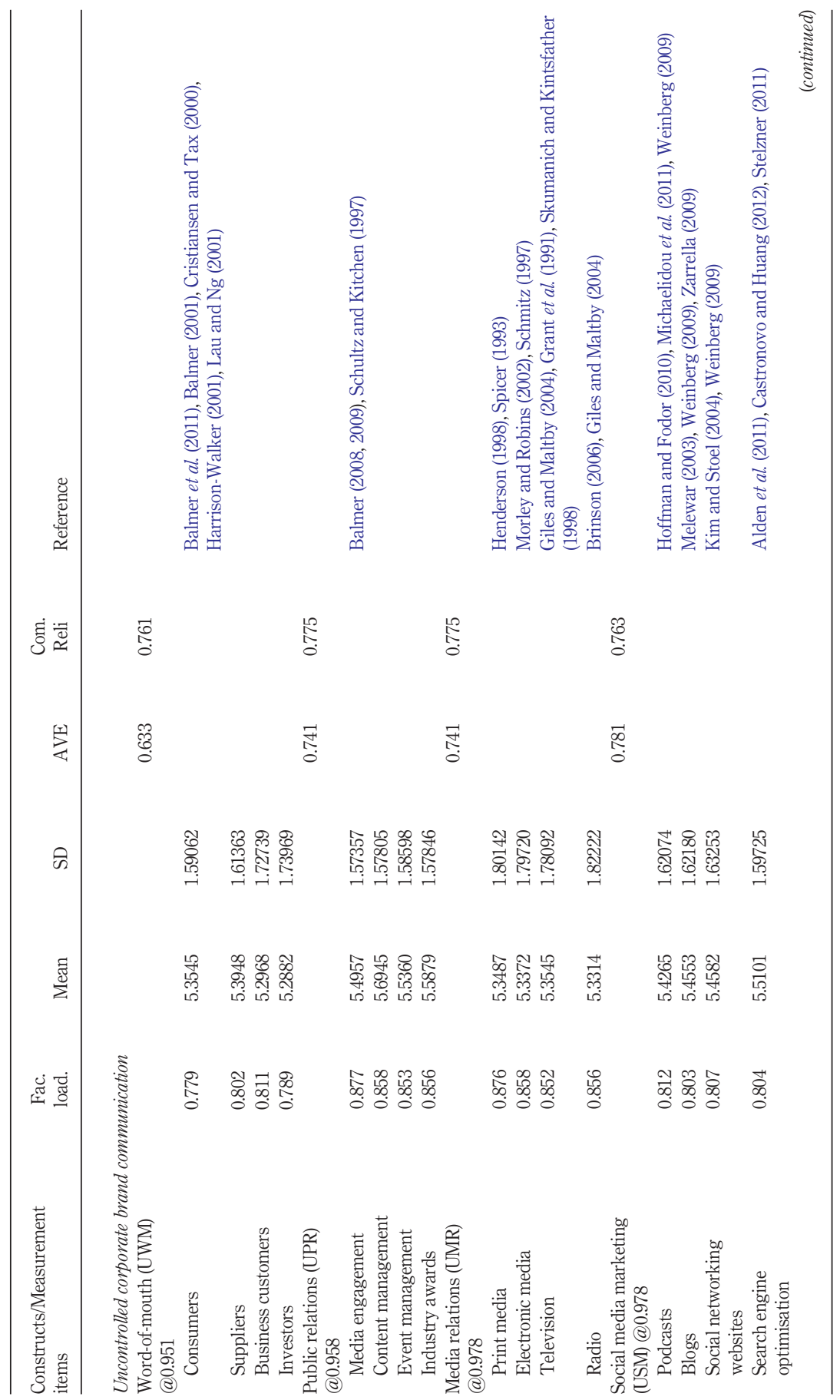

Trust, loyalty and commitment

603

Table AI. 
EJM

51,3

604

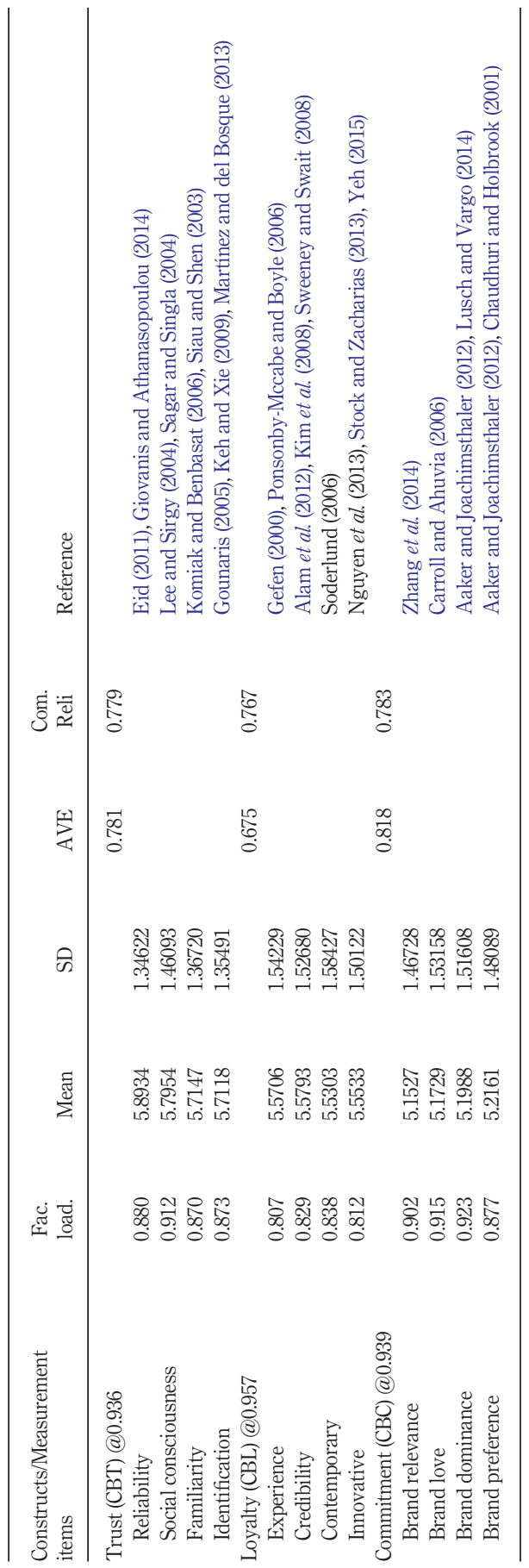

Table AI. 